\title{
PENGARUH POSISI MATAHARI DAN LETAK GEOGRAFIS TERHADAP RASYDUL QIBLAH HARIAN DI INDONESIA
}

\author{
A. Jamil \\ Institut Agama Islam Negeri Metro \\ Email : ayahjami159@yahoo.co.id
}

\begin{abstract}
Abstrak : Rasyd al-qiblah ada dua macam yakni rasyd al-qiblah global atau tahunan dan rasyd al-qiblah global atau tahunan dan rasyd alqiblah lokal atau harian. Di Indonesia bagian Barat (Selatan khattulistiwa) rasyd al-qiblah harian terjadi sepanjang tahun dari 1 januari samapi 31 desember, meskipun ada perbedaan waktunya antara daerah dan antara bulan. Fokus seberapa besar pengaruh posisi matahari dan letak geografis suatu tempat dari kakbah terhadap saat terjadinya rasyd al-qiblah harian di Indonesia? Dengan tujaun untuk mengetahui seberapa besar pengaruh posisi matahari dan letak geografis suatu tempat tehadap rasyd al-qiblah harian di Indonesia. Penelitian ini menggunakan sampel purpossif Ada fenomena lain yang menarik di daerah yang letak geografisnya di sekitar khattulistiwa seperti Bukit Tinggi dan sekitarnya ketika posisi matahari berada di sekitar garis balik selatan saat rasyd al-qiblah lebih awal dibandingkan dengan daerah yang relatif jauh dari khattulistiwa seperti Bayuwangi. Demikian juga dengan daerah yang bujurnya lebih dekat dengan Mekah misalnya Indonesia Bagian Barat (WIB) sepanjang tahun terjadi rasyd al-qiblah lokal, sedangkan daerah yang bujurnya jauh dari Mekah Seperti Indonesian Bagian Tengah dan Bagian Timur; pada saat posisi matahari jauh di sekitar garik balik Utara dan Selatan tidak terjadi rasyd al-qiblah bahkan bisa mencapai kurun waktu satu bulan lebih untuk masing-masing posisi.

Posisi matahari dan letak geografis dari kakbah mempengaruhi saat peristiwa rasyd al-qiblah dan pengaruh posisi matahari lebih dominan dibandingkan letak geografis karena letak geografis bersifat tetap sedangkan peristiwa rasyd al-qiblah dilokasi yang sama waktunya berbeda-beda disebabkan posisi matahari yang selalu berubah-ubah sepanjang waktu.
\end{abstract}

Kata kunci: posisi matahari, letak geografis, rasydul qiblah. 


\section{Pendahuluan}

\section{A. Latar Belakang Masalah}

Masalah kiblat adalah masalah arah, yakni arah Ka'bah di Mekah. Arah Ka'bah ini dapat ditentukan dari setiap titik atau tempat di permukaan bumi dengan melakukan perhitungan dan pengukuran. Penentuan arah kiblat pada setiap titik di permukaan bumi diukur berdasarkan besaran sudut dari masingmasing titik atau tempat ke arah kakbah di Mekah melalui lingkaran besar pada permukaan bumi. Berapa besar sudut arah kiblat masing-masing kota atau negara di berbagai belahan bumi tergantung dengan letak geografis kota atau negara tersebut dari Kakbah di Mekah, tidak melihat jauh atau dekatnya.

Arah Kiblat Indonesa diukur dari Utara ke arah Barat mengingat letak geografis Indonesia berada di sebelah Timur Mekah serong ke arah Selatan (arah Tenggara) yang berarti bertanda positif. Besaran sudut arah kiblat Indonesia berkisar antara $64^{\circ} 21^{\prime}$ daerah Belimbing (Lampung) dengan lintang $05^{\circ} 56^{\prime}$ (Selatan) dengan bujur $104^{\circ} 21^{\prime}$ Timur yang terletak di belahan Barat Indonesia sampai dengan $69^{\circ} 50^{\prime}$ daerah Merauke lintang $-08^{\circ} 30^{\prime}$ (Selatan) dengan bujur $140^{\circ} 27^{\prime}$ Timur yang terletak di wilayah Indonesia Timur. ${ }^{1}$

Penentuan arah kiblat dapat dilakukan dengan metode rasyd al-qiblah baik global maupun lokal. Dari kedua macam rasyd al-qiblah ini secara umum di wilayah Indonesia dapat dilakukan sepanjang tahun kecuali daerah tertentu terutama daerah yang terletak di Utara khatulistiwa seperti Banda Aceh, Medan, Pekan Baru, Manado, Boloang Mangondow sama sekali tidak bisa menggunakan rasyd al-qiblah baik global maupun lokal dan wilayah Indonesia bagian Tengah dan bagian Timur, terutama bulan Desember dan Juni juga tidak bisa mengukur arah kiblat dengan rasyd al-qiblah.

Untuk wilayah Indonesia bagian Barat yang letaknya di Selatan khattulistiwa rasyd al-qiblah terjadi sepanjang tahun, meski secara umum antara satu daerah dengan daerah lainnya; berbeda-beda. Namun ada beberapa daerah yang memiliki kesamaan waktu antar daerah yang satu dengan daerah ldapat perbedaan dari bulan ke bulan sepanjang tahun.

Mencermati fenomena saat rasyd al-qiblah yang berbeda-beda antar daerah bahkan berbeda dari bulan ke bulan dan adanya persamaan antara daerah yang satu dengan daerah lainnya, menarik untuk diletili dalam upaya mengkaji dan mengembangkan kajian astronomi dalam Islam sehingga dapat diketahui seberapa besar pengaruh posisi matahari dan letak geografis suatu tempat dari kakabah terhadap saat terjadinya rasydul qiblah harian.

Berdasarkan pada latar belakang masalah di atas, yang menjadi fokus penelitian ini, adalah:

\footnotetext{
${ }^{1}$ A. Jamil, Arah Kiblat Indonesia, (Jakarta: Rajawali Pres, 2010), h. 25
} 
1. "Seberapa besar pengaruh posisi matahari dan letak geografis suatu tempat dari kakbah terhadap saat terjadinya rasyd al-qiblah harian di Indonesia"?

2. Apakah posisi matahari atau letak geografis dari kakbah yang lebih dominan mempengaruhi saat rasyd al-qiblah harian di Indonesia?

Adapaun tujuan penelitian ini adalah untuk mengetahui:

1. Pengaruh posisi matahari dan letak geografis suatu tempat dari kakabah terhadap rasyd al-qiblah harian di Indonesia.

2. Posisi matahari atau letak geografis dari kakbah yang lebih dominan mempengaruhi rasyd al-qiblah harian di Indonesia.

Penelitian ini memiliki signifikansi sebagai berikut :

1. Memberikan kontribusi secara astronomis mengenai factor penyebab terjadinya perbedaan dan persamaan saat rasyd al-qiblah harian di berbagai daerah di Indonesia sepanjang tahun

2. Memberikan konfirmasi secara ilmiah tentang faktor dominan penyebab terjadinya perbedaan dan persamaan waktu saat rasyd alqiblah harian di berbagai daerah di Indonesia sepanjang tahun

3. Memberikan keyakinan kepada masyarakat bahwa rasyd al-qiblah harian dapat dibuktikan kebenarannya secara ilmiah sehingga masyarakat semakin percaya dan memanfaatkan rasydul qiblah harian dalam penentuan arah kiblat, yang dapat dilakukan dengan mudah dan biaya murah dengan akurasi yang tinggi.

Penelitian ini penelitian kualitatif (qualitative research), yaitu suatu penelitian yang ditujukan untuk mendeskripsikan dan menganalisa fenomena, peristiwa, aktivitas sosial, sikap, kepercayaan, persepsi, pemikiran orang secara individual maupun kelompok, ${ }^{2}$ walaupun sebagian datanya kuantitatif. Sedangkan sifat dari penelitian ini adalah deskriptif-analitis. Penelitian deskriptif merupakan studi yang bertujuan mengungkap fenomena dan fakta dengan interpretasi yang tepat. Sedangkan pada studi analitis, analisis ditujukan untuk menguji asumsi-asumsi dengan melakukan interpretasi yang lebih dalam tentang hubungan-hubungan. ${ }^{3}$

Jenis data terdiri dari data primer dan data skunder baik data kualitatif maupun data kuantitatif. Data kualitatif berupa teori atau pemikiran yang berbentuk tulisan-tulisan bersumber dari dokumentasi, sedangkan data kuantitaif berkaitan dengan data matahari seperti deklenasi $(\delta)$ matahari, equation of time $(e)$, lintang $(\varphi)$ dan bujur $(\lambda)$ tempat. Populasi penelitian seluruh wilayah waktu Indonesia. Sampel adalah sebagian atau wakil dari

\footnotetext{
${ }^{2}$ Sukmadinata, Metode Penelitian Pendidikan, (Bandung: Remaja Rosdakarya, 2006), h. 60 .

${ }^{3}$ Moh Nazir, Metode Penelitian, (Jakarta: Ghalia Indonesia, 1988), h. 105.
} 
populasi yang akan diteliti ${ }^{4}$. Menggunakan sampel purpossive untuk daerah, bulan dan tanggal dan purpossive area sampling untuk wilayah Indonesia, ${ }^{5}$ Dalam hal ini sampel wilayah mengambil wilayah Indonesia Bagian Barat, sedangkan sampel daerah atau kota mengambil sampel, dengan mempertimbangkan lintang dan bujur yang mewakili wilayah masing-masing; selain mewakili daerah yang ada rasyd al-qiblah dan yang tidak ada rasyd alqiblah.

Untuk sampel bulan peneliti mengambil sampel bulan Februari pada saat posisi matahari berda di dekat khatulistiwa, April pada saat posisi matahari berda antara khatuslistiwa dan garis balik Utara, Juni posisi matahari berada di sekitar garis balik Utara, Agustus posisi matahari berada di antara garis balik Utara dan khatulistiwa, Oktober posisi matahari berada antara garis balik Selatan dan khatulistiwa dan Desember posisi matahari berada pada garis balik Selatan. Adapun tanggal peniliti sampel tanggal 1, 15 dan 30 kecuali bulan Februari sampelnya tanggal 1, 14 dan 28.

Adapun sampel daerah yang diambil secara purpossive area sampling sebanyak 34 daerah terdiri dari 16 daerah di Sumatera dan 18 daerah di Pulau Jawa. yaitu daerah yang dekat dengan khatulistiwa, jauh dari khatulistiwa dan yang tengah-tengah, selain berdasarkan lintang juga diambil berdasarkan bujur yakni yang paling timur, paling barat dan tengah-tengah antara barat dan timur. Analisa data merupakan kegiatan mengurai data yang diawali oleh proses menghimpun data, mengolah data dengan cara melakukan perhitunganperhitungan sesuai dengan langkah dan rumus yang digunakan, dilanjutkan dengan memilah-milah, mengelompokkan, ke dalam kategori-kategori tertentu untuk diorganisir ke dalam pola, kategori sehingga dapat diurai dengan logis, sistimatis dan ditemukan makna untuk menjawab pertanyaan penelitian yang diajukan. ${ }^{6}$

B. Posisi Matahari

Perbedaan waktu saat matahari mengarah ke kakbah dari hari ke hari disebabkan gerak harian dan gerak tahunan matahari yang berlaku sepanjang tahun. Menurut Tjasyono gerakan semu matahari dibatasi oleh garis lintang $23,5^{\circ}$ Utara yang disebut tropis Cancer atau lebih dikenal dengan istilah garis balik Utara dan garis lintang $23,5^{\circ}$ Selatan yang disebut dengan tropis Capricorn atau garis balik Selatan. ${ }^{7}$ Sementara posisi matahari ketika berada

\footnotetext{
${ }^{4}$ Suharsimi Arikunto, Prosedur Penelitian Suatu Pendekatan Praktek, (Jakarta : Rineka Cipta, 1993), h. 104

${ }^{5}$ Baca Mohammad Ali, Op. cit, h. 65

${ }^{6}$ Lexy J Moleong, Metodologi Penelitian Kualitatif, (Bandung: Remaja Rosdakarya, 2007), h. 280.

${ }^{7}$ Tjasyono, B., Ilmu Kebumian dan antariksa (Bandung: Remaja Rosda Karya, 2008)

h. 70
} 
tepat di khatulistiwa disebut dengan istilah equinoks ${ }^{8}$ yaitu pada tanggal 21 Maret dan 23 september. Posisi matahari paling jauh di Utara dengan jarak $23,5^{\circ}$ dan sejajar dengan lintang $23,5^{\circ}$ Utara terjadi pada tanggal $22 \mathrm{Juni}$ atau paling jauh di Selatan dengan jarak $-23,5^{\circ}$ pada lintang $23,5^{\circ}$ tanggal 22 Desember. Jalur perjalanan tahunan matahari itu tidak berhimpit dengan equator langit, tetapi ia membentuk sudut sekitar 23o 27' dengan equator. Jalur perjalanan matahari inilah yang disebut dengan ekliptika atau da'iratu al-buruj yakni lingkaran besar pada bola langit yang memotong lingkaran equator langit dengan membentuk sudut sekitar 230 27'.

Akibat dari gerakan semu matahari menyebabkan jarak matahari dari khatulistiwa langit selalu berubah-ubah, ini dinamakan deklinasi matahari yang disimbolkan dengan huruf Yunani $(\delta)$, dalam bahasa Arab disebut dengan mail yaitu jarak matahari dari ekuator langit diukur sepanjang lingkaran deklinasi dihitung dari ekuator langit sampai titik pusat matahari. ${ }^{10}$ Deklinasi (dalam dalam penelitian ini disebut dengan istilah posisi) matahari $(\delta)$ adalah jarak matahari dari khatulistiwa langit baik ke arah Utara maupun kearah Selatan, Deklinasi matahari $(\delta)$ diukur mulai dari $0^{\circ}$ (equator langit) ke arah kutub Utara maupun ke arah kutub Selatan langit, sampai ke matahari. ${ }^{11}$

Deklinasi matahari berubah sewaktu-waktu selama satu tahun, tetapi pada tanggal-tanggal yang sama, nilai deklinasi kira-kira sama pula, yang berarti pada tanggal-tanggal tersebut posisi matahari sama dari tahun ke tahun. Tanggal 21 Maret sampai tanggal 23 September deklinasi matahari positif (+) karena berada di belahan Utara khatulistiwa, sedang dari tanggal 23 September sampai 21 Maret deklenasi matahari negatif (-), karena berada di belahan Selatan khatulistiwa yang berarti posisi matahari ada di sebelah Selatan khatulistiwa. Tanggal 21 Maret dan tanggal 23 September deklinasi matahari tepat di khatulistiwa, artinya posisi matahari tepat di khatulistiwa yang berarti deklinasi atau jarak matahari ke khatulistiwa adalah $0^{\circ} .{ }^{12}$

Setelah tanggal 21 Maret posisi matahari berangsur-angsur bergerak ke Utara menjauhi khatulistiwa, semakin lama semakin jauh. Tanggal 22 Juni posisi matahari mencapai kedudukan yang paling jauh dari khatulistiwa, yaitu $23^{0} 27^{\prime}$ Utara. Selanjutnyamatahari bergerak ke arah khatulistiwa, dansemakin lama semakin mendekati khatulistiwa. Pada tanggal 23 September posisi matahari berkedudukan di khatulistiwa lagi. Selanjutnya matahari bergeser

\footnotetext{
${ }^{8}$ Jalur perjalanan tahunan matahari itu tidak berhimpit dengan equator langit, tetapi ia membentuk sudut sekitar $23^{\circ} 27^{\prime}$ dengan ekuator. Lihat M. Khazin, 2004, h. 126.

${ }^{9}$ Ibid. 2004), h. 128

${ }^{10}$ Baca M. Khazin, Ilmu falak dalam teori dan praktek, (Yogyakarta: Buana Pustaka,

${ }^{11}$ Equator langit merupakan lingkaran besar yang berjarak $90^{0}$ dari kutub langit. Definisi lain dari equator langit adalah lingkaran besar yang di dalamnya terdapat equator bumi yang memotong bola langit.

${ }^{12}$ Lihat Abdur Rachim Ahmad, Ilmu Falak, (Yogyakarta: Liberty, 1983), h. 8
} 
menuju ke arah Selatan khatulistiwa, sampai pada tanggal 22 Desember posisi matahari mencapai titik paling jauh di Selatan khatulistiwa dengan jarak $23^{0}$ 26' Selatan. Tanggal 23 Desember kembali berangsur-angsur bergerak menuju arah khatulistiwa sampai tanggal 21 Maret posisi matahari kembali berkedudukan tepat di khatulistiwa. ${ }^{13}$

C. Letak Geografis

Letak geografis suatu tempat adalah jarak suatu tempat dari khatulistiwa diukur melalui lingkaran kutup, yang disebut dengan lintang atau fi dan disimbolkan dengan $(\varphi)$; dan jarak suatu tempat dari garis bujur standar di Greenwich Inggris yang disebut dengan bujur dan disimbulkan dengan lamda $(\lambda)$

Wilayah Indonesia letak geografisnya cukup luas mulai dari Sabang lintang $5^{\circ} 53^{\prime}$ (Utara) bujur 95³0'(Timur) sampai Merauke lintang $8^{\circ} 29^{\prime}$ (Selatan) bujur $140^{\circ} 27^{\prime}$ (Timur). Wilayah Indonesia yang membentang luas dari Sabang sampai Merauke dilihat dari letak geografis (lintang) dapat dibagi menjadi dua bagian: yaitu (1). Wilayah lintang Utara meliputi sebagian Sumatera, seperti Provinsi Daerah Istimewa Banda Aceh, Provinsi Sumatera Utara, Sebagian Provinsi Riau, Kepulauan Batam, sebagian Kalimantan, Manado, Boloang Mangondow dan sebagian dari wlayah Kepulauan Maluku. (2). Wilayah lintang Selatan terdiri dari Provinsi Sumatera Barat, sebagian kecil wilayah Provinsi Riau, Provinsi Bengkulu, Jambi, Sumatera Selatan dan Provinsi Lampung. Seluruh Pulau Jawa, Bali, Lombok, Nusa Tenggara, sebagian besar wilayah Kalimantan kecuali sebagian kecil Provnsi Kalimantan Barat dan Kalimantan Tengah, wilayah kepulauan Sulawesi, Papua dan sebagian wilayah ke pulauan Maluku.

Dengan demikian sebagian kecil wilayah Indonesia berada di Utara sedang sebagian besar terletak di Selatan khatulistiwa, hal ini berarti sebagian besar wilayah Indonesia bisa terjadi rasyd al-qiblah lokal.

D. Rasyd al-Qiblah Harian (Lokal)

Rasyd al-qiblah adalah ketentuan waktu di mana posisi matahari saat tertentu sinar matahari atau bayang-bayang sinar matahari tepat mengarah ke kakbah di Mekah ${ }^{14}$. Pada saat rasyd al-qiblah sinar matahari atau bayangbayang sebuah benda yang terpancang tegak lurus akan tepat mengarah ke kakbah. Rasyd al-qiblah ada dua macam yakni rasyd al-qiblah global yang terjadi setahun dua kali pada saat istiwa' a'dham atau saat matahari kulminasi di Mekah matahari tepat berada di atas kakbah sehingga sinar matahari tepat mengarah ke kakbah. Selain pada saat istiwa' utama matahari juga dari hari ke

\footnotetext{
${ }^{13}$ Rata-rata dari 4 tahun (2013-2016) dari winhisab

${ }^{14}$ Susiknan Azhari, Ilmu Falak; Perjumpaan Khazanah Islam dan Sains Modern, (Yogyakarta: Suara Muhammadiyah, 2007), h 79
} 
hari akan mengara ke kakbah ${ }^{15}$ dengan waktu yang berbeda-beda baik dari hari ke hari maupun antara satu daerah dengan daerah lainnya.

Peritiwa rasyd al-qiblah baik global yang terjadi dua kali dalam setahun yakni pada tanggal 27 atau 28 Mei dan tanggal 15 atau 16 Juli, maupun lokal yang bisa terjadi sepanjang tahun tidak berlaku untuk seluruh wilayah di berbagai belahan bumi; bahkan untuk Indonesia sendiri wilayah yang berada di Utara khatulistiwa seperti Aceh, Medan, Manado tidak mengalami peristiwa rasyd al-qiblah bahkan di wilayah yang terletak di Selatan khatulistiwa ada beberapa daerah di wilayah tengah dan wilayah timur yang tidak mengalami peristiwa ini terutama pada bulan Juni dan Desember setiap tahunnya.

Wilayah Indonesia yang terletak di Selatan khatulistiwa peristiwa rashd al-qiblah bisa terjadi setiap hari, terutama wilayah Indonesia bagian Barat, yakni Sumatera, Jawa, Kaalimantan Barat dan Kalimantan Tengah. Wilayah bagian tengah seperti Kalimantan Selatan, Kalimantan Timur, Sulawesi, Bali, Nusa Tenggara, Lombok, ada beberapa daerah pada bulan Juni dan Desember tidak terjadi peristiwa rasyd al qiblah; termasuk wilayah bagian timur seperti Papua, dan kepulauan Maluku; baik ketika posisi matahari di khatulistiwa, jauh di garis balik Utara maupun jauh di garis balik Selatan.

Dengan demikian peristiwa rasyd al-qiblah baik global (tahunan) maupun lokal (harian) erat kaitannya dengan posisi matahari dan letak geografis suatu tempat baik bujur terutama lintang.Hal ini terbukti daerah yang terletak di Utara khatulistiwa (lintang Utara) dengan bujur di atas 90 derajat, seperti Banda Aceh, Medan, Manado, Boloang Mongondow tidak ada rasyd alqiblah tetapi bagi wilayah meski letak di Utara khatulistiwa tetapi bujurnya kurang dari 90 derajat ada peristiwa rasyd al-qiblah meski tidak sepanjang tahun. Demikian juga di daerah yang memiliki bujur di atas 120 derajat bulan Desember dan Juni tidak terjadi rasyd al-qiblah meskipun terletak di Selatan khatulistiwa, baik disebabkan matahari belum terbit untuk bulan Desember maupun karena matahari sudah terbenam bulan Juni atau karena memang tidak ada peristiwa rasyd al-qiblah di daerah tersebut. ${ }^{16}$

Ada fenomena lain yang menarik di daerah yang letak geografisnya (lintang) di sekitar khatuslistiwa seperti Bukit Tinggi dan sekitarnya ketika posisi matahari berada di sekitar garis balik selatan saat rasyd al-qiblah lebih awal dibandingkan dengan daerah yang relatif jauh dari khatulistiwa seperti Banyuwangi. Demikian juga dengan daerah yang bujurnya lebih dekat dengan Mekah misalnya Indonesia Bagian Barat (WIB) ternyata sepanjang tahun terjadi rasyd al-qiblah lokal, sedangkan daerah yang bujurnya jauh dari Mekah seperti Indonesia Bagian Tengah (WITA) terlebih Wilayah Bagian Timur (WIT); pada saat posisi matahari berada jauh di sekitar garis balik Utara dan

h. 70

${ }^{15}$ Lihat juga Ahmad Izzzuddin, Ilmu Falak Praktis, (Semarang: Pustaka Rizki, 2012),

${ }^{16}$ A. Jamil dan Sakirman, Ibid, h. 54-57 
sekitar garis balik Selatan tidak terjadi rasyd al-qiblah bahkan bisa mencapai kurun waktu satu bulan lebih untuk masing-masing posisi ${ }^{17}$.

\section{Temuan Dan Pembahasan}

"Pengaruh Posisi Matahari dan Letak Geografis Terhadap Rasyd alQiblah Harian di Indonesia" dengan mengambil sampel purposive area sampling sebanyak 34 daerah kabupaten/kota, dimaksudkan untuk melihat pengaruh posisi matahari dan letak geografis suatu tempat terhadap rasyd alqiblah harian; selain untuk mengetahui apakah posisi matahari atau letak geografis yang lebih dominan dalam mempengaruhi perbedaan rasyd al-qiblah harian di Indonesia.

Untuk melihat pengaruh posisi matahari dan letak geografis terhadap rasyd al-qiblah harian ini langkah yang harus ditempuh pertama mencari arah kiblat tempat dan untuk mencari arah kiblat diperlukan lintang dan bujur tempat selain lintang dan bujur Kakbah. Setelah diketahui arah kiblat tempat langkah kedua mencari sudut bantu (p) masing-masing daerah dan selanjutnya dengan sudut bantu (p) akan dicari sudut saat matahari mengarah ke kakbah yang dikenal dengan istilah (c-p). Setelah diketemukan sudut (c-p) langkah selanjutnya mencari nilai $[\mathrm{p}+(\mathrm{c}-\mathrm{p})]$, dan mencari nilai $(\mathrm{C})$ dengan cara nilai [p+(c-p)] hasilnya dibagi 15; mencari nilai Meridian Pass (MP) dan langkah terakhir masuk rumus saat matahari mengarah ke kakbah, yaitu $[\mathrm{MP}+\mathrm{C}+\mathrm{KWD})]$.

Semakin dekat letak geografis suatu tempat dari khatulistiwa sudut bantu (p) semakin besar dan sebaliknya semakin jauh dari khatulistiwa sudut bantu (p) semakin kecil. Limapuluh Koto misalnya lintang $\left(-00^{\circ} 01^{\prime}\right)$ bujur $\left(100^{\circ} 34^{\prime}\right)$ Timur nilai (p) $-89^{\circ} 57^{\prime} 47^{\prime \prime}$, Metro dengan lintang $\left(-5^{\circ} 7^{\prime}\right)$ bujur $\left(105^{\circ} 18^{\prime}\right)$ sudut (p) nya $\left(-79^{\circ} 15^{\prime} 37^{\prime \prime}\right)$ Banyuwangi lintang $\left(-08^{\circ} 14^{\prime}\right)$ bujur $\left(114^{\circ} 23^{\prime}\right)$ nilai sudut $(\mathrm{p})-72^{\circ} 03^{\prime} 54$. Sudut bantu (p) selain digunakan untuk mencari nilai sudut (c-p) juga akan diakumulasikan dengan nilai (c-p) dengan rumus $[(\mathrm{p})+(\mathrm{c}-\mathrm{p})]$. Sedangkan nilai $(\mathrm{C})$ merupakan salah satu unsur yang ikut menentukan saat terjadi rasyd al-qiblah, selain meridian pass (MP) dan koreksi waktu daerah (KWD).

Untuk melihat pengaruh posisi matahari dari kakbah dengan letak geografis suatu tempat yakni jarak suatu tempat dari kakbah dapat dicermati melalui besar kecilnya sudut (c-p), karena sudut (c-p) merupakan hasil perhitungan dari unsur posisi matahari dari kakbah, letak geogafis dari kakbah (lintang dan bujur tempat) serta sudut bantu (p).

Tanggal 1 Februari misalnya dengan posisi matahari dari kakbah $\left(38^{\circ} 27^{\prime} 41^{\prime \prime}\right)$ di Selatan kakbah nilai sudut (c-p) hampir sama yakni; Limapuluh Koto $\left(47^{\circ} 11^{\prime} 17^{\prime \prime}\right)$, Padang $\left(48^{\circ} 09^{\prime} 45^{\prime \prime}\right)$, Sorolangun $\left(48^{\circ} 17^{\prime} 42^{\prime \prime}\right)$, Tj. Pandan

\footnotetext{
${ }^{17}$ A. Jamil dan Sakirman, Ibid, hal 189
} 
$\left(46^{\circ} 29^{\prime} 00^{\prime \prime}\right)$, Belitung $\left(46^{\circ} 32^{\prime} 52^{\prime \prime}\right)$ dan Palembang $\left(48^{\circ} 12^{\prime} 14^{\prime \prime}\right)$. Berbeda dengan tanggal 14 Februari di mana posisi matahari dari kakbah lebih dekat dibanding dengan tanggal 1 Februari dengan nilai ( $\left.34^{\circ} 22^{\prime} 20^{\prime \prime}\right)$, besaran sudut (c-p) antara satu daerah dengan daerah lain hampir sama namun lebih besar jika dibanding dengan sudut (c-p) pada tanggal 1 Februari yakni; Limapuluh Koto $\left(60^{\circ} 15^{\prime} 30^{\prime \prime}\right)$, Padang $\left(60^{\circ} 51^{\prime} 45^{\prime \prime}\right)$, Sorolangun $\left(60^{\circ} 56^{\prime} 42^{\prime \prime}\right)$, Tj. Pandan

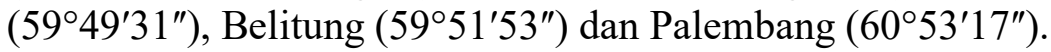

Tanggal 14 Februari dengan posisi matahari $\left(34^{\circ} 22^{\prime} 20^{\prime \prime}\right)$ dari kakbah sudut (c-p) hampir sama yakni; Brebes $\left(62^{\circ} 17^{\prime} 15^{\prime \prime}\right)$, Musi Rawa $\left(61^{\circ} 33^{\prime} 12^{\prime \prime}\right)$, Jepara $\left(61^{\circ} 34^{\prime} 03^{\prime \prime}\right)$, Simpang Pematang $\left(61^{\circ} 33^{\prime} 20^{\prime \prime}\right)$ dan Bojonegoro $\left(60^{\circ} 31^{\prime} 12^{\prime \prime}\right)$. Pada tanggal 15 April $\left(11^{\circ} 35^{\prime} 17^{\prime \prime}\right)$ dan 15 Juni posisi matahari semakin dekat dengan kakbah yakni (1 $\left.{ }^{\circ} 53^{\prime} 42^{\prime \prime}\right)$ di Utara kakbah. Nilai sudut (c-p) ketika posisi matahari lebih dekat dengan kakbah semakin besar, tanggal

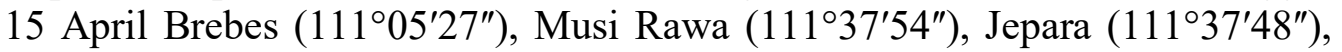
Simpang Pematang $\left(111^{\circ} 37^{\prime} 48^{\prime \prime}\right)$ dan Bojonegoro (111 $\left.37^{\prime} 45^{\prime \prime}\right)$. Tanggal 15

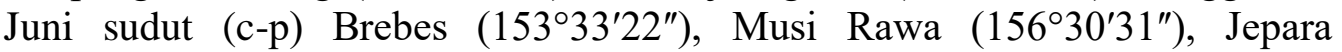
$\left(156^{\circ} 30^{\prime} 02^{\prime \prime}\right)$, Simpang Pematang $\left(156^{\circ} 27^{\prime} 01^{\prime \prime}\right)$ dan Bojonegoro (156 $\left.43^{\prime} 28^{\prime \prime}\right)$.

Demikian pula halnya dengan tanggal 28 Februari posisi matahari dari kakbah lebih dekat dari tanggal 14 yakni $\left(29^{\circ} 18^{\prime} 46^{\prime \prime}\right)$; nilai sudut (c-p) semakin bertambah besar dibanding dengan nilai (c-p) tanggal 1 dan 14 Februari, mencapai hampir 25 derajat; sementara setiap perbedaan 15 derajat menyebabkan seisih waktu sekitar satu jam. Pada bulan April posisi matahari masih di Selatan kakbah tetapi jarak dari kakbah lebih dekat dibanding bulan Februari dan pada bulan Juni posisi matahari berada di sekitar kakbah bahkan sejajar dengan kakbah. Posisi matahari pada tanggal 1 April (16 $\left.48^{\prime} 25^{\prime \prime}\right)$,

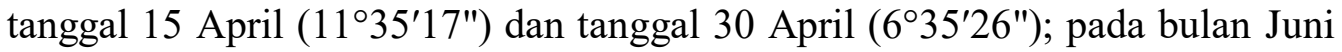
posisi matahari semakin dekat dengan kakbah yakni tangggal 1 Juni $\left(00^{\circ} 39^{\prime} 30^{\prime \prime}\right)$ di Utara, 15 Juni $\left(1^{\circ} 53^{\prime} 42^{\prime \prime}\right)$ dan 30 Juni $\left(1^{\circ} 44^{\prime} 18^{\prime \prime}\right)$ di Utara kakbah.

Nilai sudut (c-p) ketika posisi matahari lebih dekat dengan kakbah semakin besar, hal ini terbukti 1 April nilai sudut (c-p) Lima Puluh Koto $\left(100^{\circ} 15^{\prime} 11^{\prime \prime}\right)$, Padang $\left(100^{\circ} 03^{\prime} 4^{\prime \prime}\right)$, Sorolangun $\left(100^{\circ} 02^{\prime} 07^{\prime \prime}\right)$, Tj. Pandan $\left(100^{\circ} 23^{\prime} 24^{\prime \prime}\right)$, Belitung $\left(100^{\circ} 19^{\prime} 24^{\prime \prime}\right)$ dan Palembang (100'18'45"). Tanggal 15 April lebih besar dibanding tanggal 1 April yakni (1). Lima Puluh Koto $\left(112^{\circ} 34^{\prime} 38^{\prime \prime}\right)$, Padang $\left(112^{\circ} 08^{\prime} 13^{\prime \prime}\right)$, Sorolangun $\left(112^{\circ} 04^{\prime} 36^{\prime \prime}\right)$, Tj. Pandan

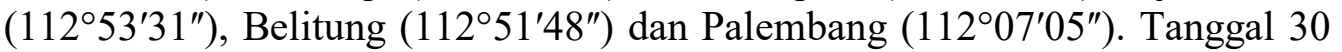
April lebih besar dibanding tanggal 1 dan 15 April yakni (1). Lima Puluh Koto $\left(125^{\circ} 55^{\prime} 36^{\prime \prime}\right)$, Padang $\left(125^{\circ} 09^{\prime} 44^{\prime \prime}\right)$, Sorolangun $\left(125^{\circ} 03^{\prime} 29^{\prime \prime}\right)$, Tj. Pandan

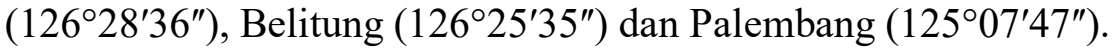

Sudut (c-p) pada bulan Juni lebih besar dibanding pada bulan April karena posisi matahari berada di sekitar kakbah dan dapat dicermati melalui sajian sebagai berikut: Tanggal 1 Juni Lima Puluh Koto (154 $\left.00^{\prime} 30^{\prime \prime}\right)$, Padang 


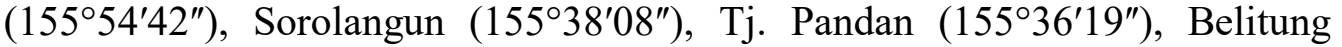
$\left(155^{\circ} 27^{\prime} 21^{\prime \prime}\right)$ dan Palembang $\left(155^{\circ} 49^{\prime} 31^{\prime \prime}\right)$. Tanggal 15 Juni lebih besar dibanding tanggal 1 Juni yakni (1). Lima Puluh Koto (162 $\left.46^{\prime} 38^{\prime \prime}\right)$, Padang $\left(159^{\circ} 38^{\prime} 00^{\prime \prime}\right)$, Sorolangun $\left(159^{\circ} 14^{\prime} 18^{\prime \prime}\right)$, Tj. Pandan $\left(165^{\circ} 24^{\prime} 49^{\prime \prime}\right)$, Belitung $\left(165^{\circ} 09^{\prime} 17^{\prime \prime}\right)$ dan Palembang $\left(159^{\circ} 30^{\prime} 34^{\prime \prime}\right)$. Tanggal 30 Juni lebih kecil dibanding tanggal 15 Juni karena posisi matahari lebih dekat dengan kakbah dibanding tanggal 15, yakni: Lima Puluh Koto (161 $\left.{ }^{\circ} 27^{\prime} 14^{\prime \prime}\right)$, Padang

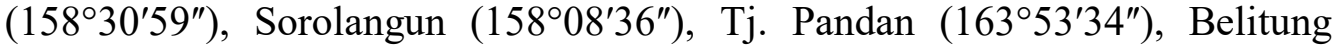
$\left(163^{\circ} 37^{\prime} 34^{\prime \prime}\right)$ dan Palembang $\left(158^{\circ} 23^{\prime} 58^{\prime \prime}\right)$.

Fenomena seperti ini tidak hanya berlaku untuk daerah yang yang berada di sekitar khatulistiwa, tetapi berlaku untuk semua wilayah termasuk yang relatif jauh dari khatulistiwa. Nilai sudut (c-p) pada tanggal 1 April untuk

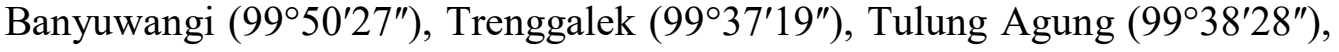

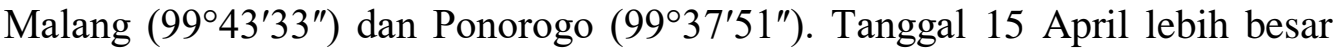

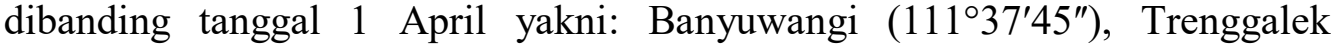
$\left(111^{\circ} 07^{\prime} 10^{\prime \prime}\right)$, Tulung Agung $\left(111^{\circ} 10^{\prime} 34^{\prime \prime}\right)$, Malang $\left(111^{\circ} 27^{\prime} 10^{\prime \prime}\right)$, dan Ponorogo $\left(111^{\circ} 09^{\prime} 08^{\prime \prime}\right)$. Tanggal 30 April lebih besar dibanding tanggal 1 dan 15 April yakni (1). Banyuwangi $\left(124^{\circ} 17^{\prime} 10^{\prime \prime}\right)$, Trenggalek $\left(123^{\circ} 24^{\prime} 45^{\prime \prime}\right)$, Tukung Agung $\left(123^{\circ} 30^{\prime} 34^{\prime \prime}\right)$, Malang $\left(123^{\circ} 50^{\prime} 24^{\prime \prime}\right)$ dan Ponorogo $\left(123^{\circ} 28^{\prime} 06^{\prime \prime}\right)$.

Sudut (c-p) pada bulan Juni untuk daerah lain yang letak geografisnya relatif jauh dari khatulistiwa, baik di Sumatera maupun di Jawa nilai sudut (cp) nya sama, yakni lebih besar dibanding pada bulan April karena posisi matahari berada di sekitar kakbah dan dapat dicermati melalui sajian sebagai berikut: Tanggal 1 Juni sudut (c-p) Banyuwangi (149 40'34"), Trenggalek $\left(147^{\circ} 31^{\prime} 30^{\prime \prime}\right)$, Tulung Agung $\left(147^{\circ} 45^{\prime} 02^{\prime \prime}\right)$, Malang $\left(148^{\circ} 32^{\prime} 58^{\prime \prime}\right)$ dan Ponorogo $\left(147^{\circ} 39^{\prime} 10^{\prime \prime}\right)$. Tanggal 15 Juni lebih besar dibanding tanggal 1 Juni yakni (1). Sudut (cp) Banyuwangi $\left(156^{\circ} 29^{\prime} 44^{\prime \prime}\right)$, Trenggalek $\left(153^{\circ} 53^{\prime} 26^{\prime \prime}\right)$, Tulung Agung $\left(153^{\circ} 53^{\prime} 26^{\prime \prime}\right)$, Malang $\left(155^{\circ} 01^{\prime} 37^{\prime \prime}\right)$ dan Ponorogo $\left(153^{\circ} 51^{\prime} 45^{\prime \prime}\right)$. Tanggal 30 Juni sudut (c-p) sedikit lebih kecil dibanding tanggal 15 Juni karena posisi matahari lebih dekat dengan kakbah dibanding tanggal 15, yakni: Banyuwangi $\left(155^{\circ} 32^{\prime} 08^{\prime \prime}\right)$, Trenggalek $\left(158^{\circ} 30^{\prime} 59^{\prime \prime}\right)$, Tulung Agung $\left(153^{\circ} 07^{\prime} 49^{\prime \prime}\right)$, Malang $\left(154^{\circ} 07^{\prime} 52^{\prime \prime}\right)$ dan Ponorogo (153 $\left.00^{\prime} 30^{\prime \prime}\right)$.

Memperhatikan paparan di atas ternyata pada tanggal dan bulan yang sama (1 April) dan (15 Juni) misalnya posisi matahari dari kakbah $\left[16^{\circ} 48^{\prime} 25^{\prime \prime}\right.$ (di Selatan)] dan [1 ${ }^{\circ} 53^{\prime} 42^{\prime \prime}$ (di Utara)] kakbah dengan daerah yang berbeda letak geografisnya nilai sudut (c-p) nya hampir sama. Setelah bulan Juni matahari bergeser ke arah khatulistiwa yang berarti posisinya semakin menjauh dari kakbah ke arah Selatan sampai mencapai titik terjauh di garis balik Selatan pada bulan Desember. Bulan Agustus misalnya nilai (c-p) lebih kecil dibanding (c-p) pada bulan Juni, demikian juga pada bulan Desember nilai sudut (c-p) lebih kecil dibanding (c-p) bulan Oktober. Tanggal 1 Agustus (c-p) Kab. Lima 
Puluh Koto (136 $\left.56^{\prime} 33^{\prime \prime}\right)$, Kota Padang (136 $\left.51^{\prime} 26^{\prime \prime}\right)$, Kab. Sorolangun (136 $\left.43^{\prime} 37^{\prime \prime}\right)$, Kab. Tj. Pandan (136 $\left.43^{\prime} 47^{\prime \prime}\right)$, Kab. Belitung (136 $\left.39^{\prime} 27^{\prime \prime}\right)$ dan Kota Palembang $\left(134^{\circ} 48^{\prime} 41^{\prime \prime}\right)$.

Tanggal 15 Agustus lebih kecil dibanding tanggal 1 Agustus yakni (1).

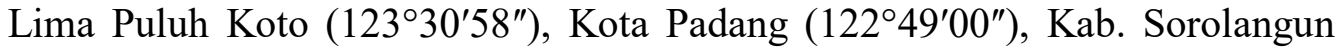

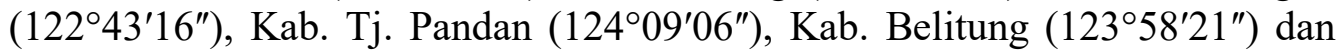
Kota Palembang $\left(122^{\circ} 47^{\prime} 13^{\prime \prime}\right)$. Tanggal 30 Agustus lebih kecil dibanding tanggal 15 Agustus karena posisi matahari lebih jauh dari kakbah dibanding tanggal 15, yakni (1). Lima Puluh Koto $\left(110^{\circ} 21^{\prime} 58^{\prime \prime}\right)$, Kota Padang

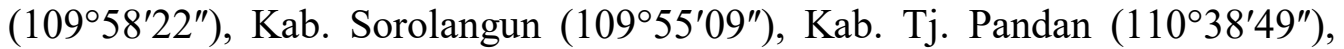
Kab. Belitung $\left(110^{\circ} 21^{\prime} 08^{\prime \prime}\right)$ dan Kota Palembang (109 57'22"). Posisi matahari pada bulan Oktober dan Desember semakin jauh dari kakbah dan sudut (c-p) nya pun semakin kecil. Jarak matahari dari kakbah pada tanggal 1 Oktober $\left(24^{\circ} 40^{\prime} 25^{\prime \prime}\right)$, tanggal 15 Otober (29 59'46") dan tanggal 30 Oktober $\left(35^{\circ} 15^{\prime} 10^{\prime \prime}\right)$; pada bulan Desember posisi matahari lebih jauh dari kakbah yakni

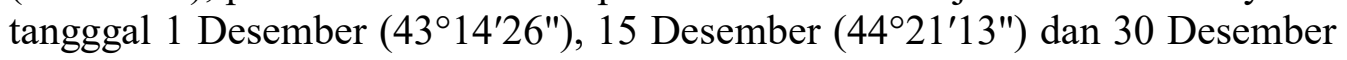
(44⒊'03") di Selatan kakbah. Dengan semakin jauhnya posisi matahari dari kakbah sudut (c-p) semakin kecil; keadaan ini dapat dicermati melalui paparan berikut:

Pada tanggal 1 Oktober dengan posisi matahari jauh dari kakbah $\left(24^{\circ} 40^{\prime} 25^{\prime \prime}\right)$ sudut (c-p) Lima Puluh Koto $\left(82^{\circ} 45^{\prime} 15^{\prime \prime}\right)$, Padang $\left(82^{\circ} 53^{\prime} 20^{\prime \prime}\right)$, Sorolangun $\left(82^{\circ} 54^{\prime} 26^{\prime \prime}\right)$, Tj. Pandan $\left(82^{\circ} 39^{\prime} 28^{\prime \prime}\right)$, Belitung $\left(82^{\circ} 40^{\prime} 00^{\prime \prime}\right)$ dan Palembang (82 53'41"). Tanggal 15 sudut (c-p) semkin mengecil yakni: (1). Lima Puluh Koto $\left(70^{\circ} 27^{\prime} 24^{\prime \prime}\right)$, (2). Padang $\left(70^{\circ} 50^{\prime} 03^{\prime \prime}\right)$, (3). Sorolangun $\left(70^{\circ} 53^{\prime} 08^{\prime \prime}\right)$, (4). Tj. Pandan (70 $\left.11^{\prime} 38^{\prime \prime}\right)$, (5). Belitung $\left(70^{\circ} 12^{\prime} 50^{\prime \prime}\right)$ dan (6). Palembang $\left(70^{\circ} 51^{\prime} 00^{\prime \prime}\right)$ dan tanggal 30 Oktober sudut (c-p) lebih kecil, Lima Puluh Koto $\left(56^{\circ} 27^{\prime} 37^{\prime \prime}\right)$, Padang $\left(57^{\circ} 35^{\prime} 52^{\prime \prime}\right)$, Sorolangun $\left(57^{\circ} 41^{\prime} 30^{\prime \prime}\right)$, Tj.

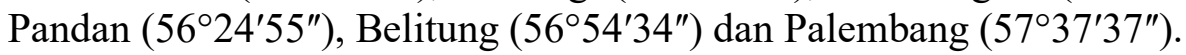

Bulan Desember posisi matahari mencapai titik terjauh di sekitar garis balik Selatan yang berarti posisi matahari paling jauh di Selatan kakbah, sehingga sudut (c-p) yang dibentuk lebih kecil. Tanggal 1 Desember sudut (cp) Lima Puluh Koto $\left(25^{\circ} 43^{\prime} 24^{\prime \prime}\right)$, Padang $\left(25^{\circ} 24^{\prime} 18^{\prime \prime}\right)$, Sorolangun $\left(25^{\circ} 40^{\prime} 18^{\prime \prime}\right)$, Tj. Pandan $\left(25^{\circ} 55^{\prime} 18^{\prime \prime}\right)$, Belitung $\left(25^{\circ} 04^{\prime} 39^{\prime \prime}\right)$ dan Palembang $\left(25^{\circ} 29^{\prime} 30^{\prime \prime}\right)$. Tanggal 15 Desember sudut (c-p) semkin mengecil yakni: Lima Puluh Koto $\left(17^{\circ} 36^{\prime} 16^{\prime \prime}\right)$, Padang $\left(20^{\circ} 41^{\prime} 12^{\prime \prime}\right)$, Sorolangun $\left(21^{\circ} 04^{\prime} 31^{\prime \prime}\right)$, Tj. Pandan $\left(15^{\circ} 02^{\prime} 27^{\prime \prime}\right)$, Belitung $\left(15^{\circ} 17^{\prime} 25^{\prime \prime}\right)$ dan Palembang $\left(20^{\circ} 48^{\prime} 30^{\prime \prime}\right)$ dan tanggal 30 Desember posisi matahari masih berada di garis balik Selatan sedikit bergeser ke arah khatulistiwa dan sudut (c-p) nya mulai berubah sebagai berikut: Lima Puluh Koto $\left(18^{\circ} 35^{\prime} 09^{\prime \prime}\right)$, Padang $\left(21^{\circ} 31^{\prime} 03^{\prime \prime}\right)$, Sorolangun $\left(21^{\circ} 53^{\prime} 24^{\prime \prime}\right)$, Tj.

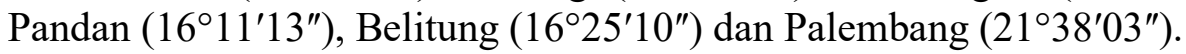

Perubahan sudut (c-p) ini berlaku untuk semua wilayah Indonesia yang letak geografisnya di Selatan khatulistiwa dengan perubahan yang sama; baik 
yang letak geografisnya di sekitar khatulistiwa yang berarti relatif dekat dari kakbah seperti Limapuluh Koto dengan jarak $\left(21^{\circ} 26^{\prime}\right)$ Padang dengan jarak $\left(22^{\circ} 22^{\prime}\right)$ maupun daerah yang relatif jauh dari kakbah seperti Banyuwangi $\left(29^{\circ} 39^{\prime}\right)$, Tulung Agung $\left(29^{\circ} 30^{\prime}\right)$, Trenggalek $\left(29^{\circ} 28^{\prime}\right)$ dan daerah Malang dengan jarak $\left(29^{\circ} 24^{\prime}\right)$. Kondisi ini dapat dipahami melalui paparan di bawah ini:

Bulan Agustus misalnya nilai (c-p) lebih kecil dibanding (c-p) pada bulan Juni, demikian juga nilai (c-p) bulan Oktober lebih kecil dari (c-p) Agustus dan (c-p) Desember lebih kecil dibanding (c-p) bulan Oktober. Tanggal 15 Agustus misalnya nilai sudut (c-p) Banyuwangi

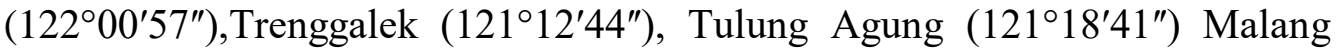
$\left(121^{\circ} 36^{\prime} 17^{\prime \prime}\right)$. Posisi matahari pada bulan Oktober dan Desember semakin jauh dari kakbah dan sudut (c-p) nya pun semakin kecil. Jarak matahari dari kakbah pada tanggal 15 Otober (29 59'46") dan tanggal 15 Desember (44²1'13"). Pada tanggal 15 Oktober sudut (c-p) semkin mengecil yakni: Banyuwangi $\left(71^{\circ} 16^{\prime} 05^{\prime \prime}\right)$, (2). Trenggalek $\left(71^{\circ} 42^{\prime} 15^{\prime \prime}\right)$, (3). Tulung Agung $\left(71^{\circ} 29^{\prime} 21^{\prime \prime}\right)$, (4). Malang $\left(71^{\circ} 29^{\prime} 25^{\prime \prime}\right)$ dan Ponorogo $\left(71^{\circ} 40^{\prime} 35^{\prime \prime}\right)$. Bulan Desember posisi matahari mencapai titik terjauh di sekitar garis balik Selatan yang berarti posisi matahari paling jauh di Selatan kakbah, sehingga sudut (c-p) yang dibentuk lebih kecil. Tanggal 15 Desember sudut (c-p) semkin mengecil yakni: (1). Banyuwangi $\left(23^{\circ} 46^{\prime} 42^{\prime \prime}\right)$, (2). Trenggalek $\left(26^{\circ} 23^{\prime} 00^{\prime \prime}\right)$, (3).Tulung Agung $\left(26^{\circ} 15^{\prime} 19^{\prime \prime}\right)$, (4). Malang $\left(25^{\circ} 13^{\prime} 34^{\prime \prime}\right)$ dan Ponorogo $\left(26^{\circ} 22^{\prime} 49^{\prime \prime}\right)$.

Paparan di atas menunjukkan bahwa perubahan sudut (c-p) antara satu daerah dengan daerah lain hampir tidak ada perbedaan dari bulan ke bulan sepanjang tahun meskipun letak geografis berbeda-beda antara satu daerah dengan daerah lainnya. ${ }^{18}$ Berbeda dengan daerah yang letak geografisnya di Selatan khatulistiwa, semakin dekat matahari dari kakbah sudut (c-p) semakin besar dan semakin jauh posisi matahari dari kakbah sudut (c-p) semakin kecil.

Daerah yang letak geografisnya di Utara khatulistiwa semakin dekat posisi matahari dari kakbah sudut (c-p) semakin kecil dan semakin jauh posisi matahari dari kakbah sudut (c-p) semakin besar. Misal jarak daerah Banda Aceh dari kakbah $\left(15^{\circ} 51^{\prime}\right)$, Belawan $\left(17^{\circ} 38^{\prime}\right)$, Bengkalis $\left(19^{\circ} 54^{\prime}\right)$, Mandailing $\left(20^{\circ} 40^{\prime}\right)$ dan Lubuk Sikaping $\left(21^{\circ} 20^{\prime}\right)$. Mengenai sudut (c-p) daerah yang letak geografisnya di Utara khatulistiwa semakin dekat matahari dengan kakbah semakin kecil dan semakin jauh matahari dari kakbah sudut (c-p) sekmakin besar dapat cermati melalui paparan berikut:

Sudut (c-p) daerah yang letak geografisnya di Utara khatulistiwa pada bulan Juni dengan posisi matahari di sekitar kakbah lebih kecil dibanding pada bulan Oktober dan Desember, karena posisi matahari pada bulan Juni berada di

penelitian ini

${ }^{18}$ Untuk lebih jelasnya dapat dicermati melalui tabel 4 .....pada lampiran laporan 
sekitar kakbah sedangkan posisi matahari pada bulan Oktober dan Desember jauh di Selatan kakbah. Tanggal 1 Juni Banda Aceh $\left(15^{\circ} 19^{\prime} 40^{\prime \prime}\right)$, Belawan

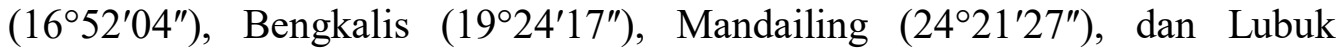
Sikaping $\left(30^{\circ} 42^{\prime} 26^{\prime \prime}\right)$. Tanggal 15 Juni lebih kecil dibanding tanggal 1 Juni yakni Banda Aceh (tidak ada), Belawan (tidak ada), Bengkalis (tidak ada), Mandailing $\left(14^{\circ} 03^{\prime} 35^{\prime \prime}\right)$, dan Lubuk Sikaping $\left(16^{\circ} 56^{\prime} 20^{\prime \prime}\right)$. Tanggal 30 Juni lebih kecil dibanding tanggal 15 Juni karena posisi matahari lebih dekat dengan kakbah dibanding tanggal 15, yakni (1). Banda Aceh (tidak ada), Belawan (tidak ada), Bengkalis $\left(161^{\circ} 39^{\prime} 56^{\prime \prime}\right)$, Mandailing $\left(16^{\circ} 08^{\prime} 45^{\prime \prime}\right)$, dan Lubuk Sikaping $\left(18^{\circ} 17^{\prime} 16^{\prime \prime}\right)$.

Pada bulan Oktober 1 (c-p) Banda Aceh (97 46 $\left.40^{\prime \prime}\right)$, Belawan $\left(97^{\circ} 43^{\prime} 02^{\prime \prime}\right)$, Bengkalis $\left(97^{\circ} 36^{\prime} 19^{\prime \prime}\right)$, Mandailing $\left(97^{\circ} 20^{\prime} 39^{\prime \prime}\right)$, dan Lubuk Sikaping (96 $\left.55^{\prime} 45^{\prime \prime}\right)$. Tanggal 15 Oktober lebih besar dibanding tanggal 1 Oktober yakni Banda Aceh $\left(110^{\circ} 01^{\prime} 48^{\prime \prime}\right)$, Belawan $\left(110^{\circ} 53^{\prime} 28^{\prime \prime}\right)$, Bengkalis $\left(110^{\circ} 31^{\prime} 39^{\prime \prime}\right)$, Mandailing (108 $\left.58^{\prime} 31^{\prime \prime}\right)$, dan Lubuk Sikaping (109 $\left.32^{\prime} 53^{\prime \prime}\right)$. Tanggal 30 Oktober lebih kecil dibanding tanggal 15 Oktober karena posisi matahari lebih jauh dengan kakbah dibanding tanggal 15, yakni (1). Banda

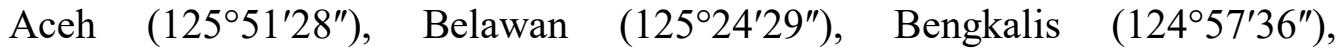

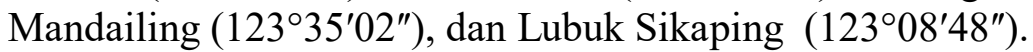

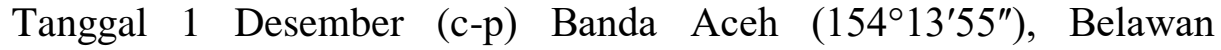

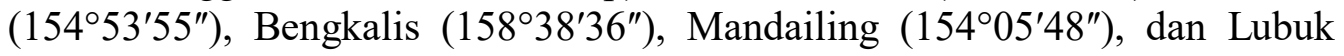
Sikaping ( $\left.148^{\circ} 05^{\prime} 57^{\prime \prime}\right)$. Tanggal 15 Desember lebih besar dibanding tanggal 1 Desember yakni Banda Aceh (tidak ada), Belawan (tidak ada), Bengkalis

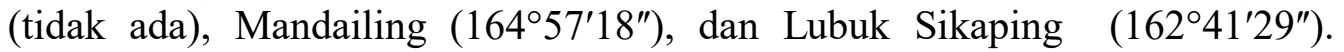
Tanggal 30 Desember Banda Aceh (tidak bisa), Belawan (tidak bisa), Bengkalis $\left(174^{\circ} 09^{\prime} 09^{\prime \prime}\right)$, Mandailing $\left(163^{\circ} 48^{\prime} 28^{\prime \prime}\right)$, dan Lubuk Sikaping $\left(161^{\circ} 40^{\prime} 10^{\prime \prime}\right)$.

Berdasarkan paparan data di atas nampak bahwa nilai sudut (c-p) selalu berubah-ubah untuk semua kota atau daerah sedangkan sudut bantu (p) berbeda antara satu daerah dengan daerah lain dan bersifat tetap. Perubahan sudut (c-p) sangat signifikan dari bulan ke bulan bahkan dalam satu bulan pun perubahan cukup signifikan rata-rata di atas 10 derajat, kecuali bulan Juni dan Desember. Perubahan dari Februari ke April dan dari April ke Juni mencapai 100 derajat lebih $\left(47^{\circ} 11^{\prime} 17^{\prime \prime}\right.$ - 161 $\left.27^{\prime} 14^{\prime \prime}\right)$, demikian juga perubahan dari Juni ke Desember mencapai 130 derajat lebih $\left(161^{\circ} 27^{\prime} 14^{\prime \prime}-18^{\circ} 35^{\prime} 09^{\prime \prime}\right)$.

Perubahan posisi matahari dari bulan ke bulan yang menyebabkan perbedaan besaran sudut (c-p) berdampak pula pada perubahan dan perbedaan nilai (C) yaitu [(p)+(c-p)]. Mengingat nilai (p) sebagian besar negatif (-) dan nilai (c-p) ada yang besar dan ada yang kecil menyebabkan nilai (C) juga ada yang besar dan ada yang kecil selain ada yang negatif dan ada yang positif. Perubahan dan perbedaan nilai (C) yang terjadi dari waktu ke waktu 
menyebabkan berbedanya saat matahari mengarah ke kakbah (rasyd al-qiblah) baik dari waktu ke waktu maupun antara satu daerah dengan daerah lainnya. ${ }^{19}$

Perbedaan saat rasyd al-qiblah yaitu saat matahari tepat megarah ke kakbah dari waktu ke waktu dan antara satu daerah dengan daerah lainnya sebagai akibat dari perubahan dan perbedaan sudut (c-p) menyebabkan adakalanya rasyd al-qiblah terjadi sore hari antara April-Juni (pukul 14:0017:00) dan antara Juni-Agustus (pukul 17:00-14:30), siang hari antara Februari-April (pukul 11:00-14:00) dan antara Agustus-Oktober (pukul 14:3011:00) demikian juga ada yang pagi hari antara Oktober-Desember (pukul 11:00-07:00) dan Desember- Februari (pukul 07:00-11:00). Selain itu antara satu daerah dengan daerah lainnya juga berbeda-beda, misalnya tanggal 15 Desember rasyd al-qiblah di daerah Tanjung Pandan terjadi pukul (07:12), Banyuwangi terjadi pukul (08:04) dan di daerah Lemong terjadi pukul 08:34. ${ }^{20}$

Perubahan dan perbedaan sudut (c-p) dari bulan ke bulan yang disebabkan perubahan posisi matahari dari kakbah dan hal ini menyebabkan adanya perbedaan saat rasyd al-qilah dari waktu ke waktu untuk semua daerah. Tanggal 14 Februari terjadi (pukul 10:33), Padang (pukul 10:44), Sorolangun (pukul 10:45), Tj. Pandan (pukul 10:27), Beliting (pukul 10:28) dan Palembang (pukul 10:44), sedangkan tanggal 15 April rasyd al-qilah Limapuluh Koto (pukul 13:48), Padang (pukul 13:55), Sorolangun (pukul 13:55) Tj. Pandan (pukul 13:45), Beliting (pukul 14:45) dan Palembang (pukul 14:55) dan 15 Juni Limapuluh Koto (pukul 17:09), Padang (pukul 17:06), Sorolangun (pukul 17:05) Tj. Pandan (pukul 17:16), Beliting (pukul 17:16) dan Palembang (pukul 17:05).

Tanggal 15 Agustus rasyd al-qbilah di daerah Limapuluh Koto terjadi pada (pukul 14:36), Padang (pukul 14:43 ), Sorolangun (pukul 14:43), Tj. Pandan (pukul 14:35), Beliting (pukul 14:34) dan Palembang (pukul 14:42), sedangkan tanggal 15 Oktober rasyd al-qilah Limapuluh Koto (pukul 10:45), Padang (pukul 10:56), Sorolangun (pukul 10:56) Tj. Pandan (pukul 10:40), Belitang (pukul 10:41) dan Palembang (pukul 10:56) dan 15 Desember Limapuluh Koto (pukul 07:23), Padang (pukul 07:53), Sorolangun (pukul 07:47) Tj. Pandan (pukul 07:12), Belitang (pukul 07:10) dan Palembang (pukul 07:45).

Perubahan dan Perbedaan nilai sudut (c-p) dari hari ke hari terjadi sepanjang waktu sementara nilai sudut bantu (p) bersifat tetap, fenomena ini menyebabkan nilai (C) yang merupakan akumulasi dari nilai $[(p+(c-p)]$

${ }^{19}$ Sebagian besar wilayah Indonesia saat peristiwa rasyd al-qiblah berbeda-beda antara satu daerah dengan daerah lainnya walaupun daerah tersebut berdekatan jaraknya, selain ada beberapa daerah yang sama walaupun letak geografisnya berbeda.

20Untuk memahami perubahan dan perbedaan ini dapat dicermati melalui tabel 2, 4 dan tabel 8 pada bagian lampiran laporan penelitian ini. 
berubah-ubah pula sesuai dengan besar kecilnya nilai sudut (c-p). Di sisi lain Meridian Pass (MP) sebagai salah satu unsur dalam penentuan saat terjadinya rasyd al-qiblah untuk wilayah Indonesia selalu berubah-ubah dan tidak sama dari hari ke hari.

Mengingat nilai sudut bantu (p) masing-masing daerah tidak sama dan bersifat tetap sedangkan nilai sudut (c-p) selalu berubah-ubah, hal ini mempengaruhi perubahan dan perbedaan saat rasyd al-qiblah dari waktu ke waktu baik di daerah (lokasi) yang sama terlebih di daerah (lokasi) yang berbeda-beda. Akibatnya ada saatnya rasyd al-qiblah terjadi pada sore hari, siang dan pagi, inipun antara satu daerah dengan daerah lainnya juga berbeda meski sama-sama pagi atau sama-sama siang. Fenomena ini dapat dicermati melalui berbagai tabel di bawah ini:

Tabel 1. Nilai Sudut Bantu (p), Nilai Sudut (c-p) dan nilai $(C)=[(p)+(c-p)] 1$ Februari

\begin{tabular}{|l|c|c|c|}
\hline \multicolumn{1}{|c|}{ Daerah } & $(\mathrm{p})$ & $(\mathrm{c}-\mathrm{p})$ & $\mathrm{C}=[(\mathrm{p})+(\mathrm{c}-\mathrm{p})]$ \\
\hline \multicolumn{1}{|c|}{$\begin{array}{l}\text { Limapuluh } \\
\text { Koto }\end{array}$} & $-89^{\circ} 57^{\prime} 47^{\prime \prime}$ & $47^{\circ} 11^{\prime} 17^{\prime \prime}$ & $-42^{\circ} 46^{\prime} 30^{\prime \prime}$ \\
\hline Padang & $-87^{\circ} 55^{\prime} 57^{\prime \prime}$ & $48^{\circ} 09^{\prime} 45^{\prime \prime}$ & $-39^{\circ} 46^{\prime} 12^{\prime \prime}$ \\
\hline Sorolangun & $-85^{\circ} 13^{\prime} 05^{\prime \prime}$ & $48^{\circ} 17^{\prime} 42^{\prime \prime}$ & $-36^{\circ} 55^{\prime} 23^{\prime \prime}$ \\
\hline Tj. Pandan & $-83^{\circ} 46^{\prime} 09^{\prime \prime}$ & $46^{\circ} 29^{\prime} 00^{\prime \prime}$ & $-37^{\circ} 17^{\prime} 19^{\prime \prime}$ \\
\hline Belitung & $-83^{\circ} 35^{\prime} 17^{\prime \prime}$ & $46^{\circ} 32^{\prime} 52^{\prime \prime}$ & $-37^{\circ} 02^{\prime} 35^{\prime \prime}$ \\
\hline Palembang & $-83^{\circ} 29^{\prime} 41^{\prime \prime}$ & $48^{\circ} 12^{\prime} 14^{\prime \prime}$ & $-35^{\circ} 17^{\prime} 27^{\prime \prime}$ \\
\hline
\end{tabular}

Berdasarkan tabel 1. di atas nilai sudut bantu (p) negatif dan berbedabeda antara satu daerah dengan daerah lain meskipun tidak signifikan. Hasil dari tabel 1. ini dikonversi menjadi jam waktu dan diakumulasikan dengan Meridian Pass (MP), Koreksi Waktu Daerah (KWD) menghasilkan saat rasyd al-qiblah sesuai tanggal dan lokasi masing-masing. Hal ini dapat dicermati melalui tabel 2. sebagai berikut:

Tabel 2. Saat Rasyd al-Qiblah 1 Februari

\begin{tabular}{|l|c|c|c|c|}
\hline \multicolumn{1}{|c|}{ Daerah } & C & MP & KWD & C+MP+KWD \\
\hline \multicolumn{1}{|c|}{1} & 2 & 3 & 4 & 5 \\
\hline Limapuluh Koto & $-2: 51: 06$ & $12: 13: 35$ & $0: 17: 44$ & $09: 40$ \\
\hline Padang & $-2: 39: 05$ & $12: 13: 35$ & $0: 18: 32$ & $09: 53$ \\
\hline Sorolangun & $-2: 27: 42$ & $12: 13: 35$ & $0: 08: 00$ & $09: 54$ \\
\hline Tj. Pandan & $-2: 29: 09$ & $12: 13: 35$ & $-0: 11: 16$ & $09: 33$ \\
\hline Belitung & $-2: 28: 10$ & $12: 13: 35$ & $-0: 11: 40$ & $09: 34$ \\
\hline Palembang & $-2: 21: 10$ & $12: 13: 35$ & $0: 00: 36$ & $09: 53$ \\
\hline
\end{tabular}

Melalui tabel 2. kolom 5 nampak bahwa saat rasyd al-qiblah pagi hari dan antara satu daerah dengan daerah lainnya tidak sama. Limapuluh Koto 
pukul (09:40), Padang, Sorolangun dan Palembang sama (09:53), Tanjung Pandan dan Belitung sama (09:34). Pada tanggal yang sama dengan daerah yang sudut (c-p) dan letak geografisnya berbeda, berbeda pula saat rasyd alqiblah walaupun sama-sama terjadi pagi hari. Hal ini Nampak pada tabel 3 sebagai berikut:

Tabel 3. Nilai Sudut Bantu (p), Nilai Sudut (c-p) dan nilai $(C)=[(p)+(c-p)] 1$ Februari

\begin{tabular}{|l|c|c|c|}
\hline \multicolumn{1}{|c|}{ Daerah } & $(\mathrm{p})$ & $(\mathrm{c}-\mathrm{p})$ & $\mathrm{C}=[(\mathrm{p})+(\mathrm{c}-\mathrm{p})]$ \\
\hline \multicolumn{1}{c|}{1} & 2 & 3 & 4 \\
\hline Musi Rawas & $-83^{\circ} 37^{\prime} 53^{\prime \prime}$ & $49^{\circ} 15^{\prime} 51^{\prime \prime}$ & $-34^{\circ} 22^{\prime} 02^{\prime \prime}$ \\
\hline Sp. Pematang & $-81^{\circ} 11^{\prime} 20^{\prime \prime}$ & $49^{\circ} 16^{\prime} 04^{\prime \prime}$ & $-31^{\circ} 55^{\prime} 16^{\prime \prime}$ \\
\hline Jepara & $-75^{\circ} 45^{\prime} 00^{\prime \prime}$ & $49^{\circ} 17^{\prime} 12^{\prime \prime}$ & $-26^{\circ} 27^{\prime} 48^{\prime \prime}$ \\
\hline Pati & $-75^{\circ} 24^{\prime} 32^{\prime \prime}$ & $49^{\circ} 15^{\prime} 48^{\prime \prime}$ & $-26^{\circ} 08^{\prime} 44^{\prime \prime}$ \\
\hline Bojonegoro & $-74^{\circ} 27^{\prime} 05^{\prime \prime}$ & $49^{\circ} 11^{\prime} 04^{\prime \prime}$ & $-25^{\circ} 16^{\prime} 01^{\prime \prime}$ \\
\hline Probolinggo & $-73^{\circ} 10^{\prime} 28^{\prime \prime}$ & $49^{\circ} 17^{\prime} 57^{\prime \prime}$ & $-23^{\circ} 52^{\prime} 31^{\prime \prime}$ \\
\hline Banyuwangi & $-72^{\circ} 03^{\prime} 54^{\prime \prime}$ & $49^{\circ} 16^{\prime} 12^{\prime \prime}$ & $-22^{\circ} 47^{\prime} 42^{\prime \prime}$ \\
\hline
\end{tabular}

Berdasarkan tabel 3. di atas nilai sudut bantu (p) negatif dan dapat dikatakan tidak ada perbedaan antara satu daerah dengan daerah lainnya. Nilai C pada kolom (4) ini dikonversi menjadi jam waktu dan diakumulasikan dengan Meridian Pass (MP) dan Koreksi Waktu Daerah (KWD) menghasilkan saat rasyd al-qiblah yang sama antara satu daerah dengan lain meski daerahnya berbeda-beda. Hal ini dapat dicermati melalui tabel 4. sebagai berikut:

Tabel 4. Saat Rasyd al-Qiblah 1 Februari

\begin{tabular}{|l|c|c|c|c|}
\hline \multicolumn{1}{|c|}{ Daerah } & C & MP & KWD & C+MP+KWD \\
\hline \multicolumn{1}{c|}{1} & 2 & 3 & 4 & 5 \\
\hline Musi Rawas & $-2: 17: 28$ & $12: 13: 35$ & $08: 48$ & $10: 05$ \\
\hline Sp. Pematang & $-2: 07: 41$ & $12: 13: 35$ & $-00: 52$ & $10: 05$ \\
\hline Jepara & $-1: 45: 51$ & $12: 13: 35$ & $-22: 36$ & $10: 05$ \\
\hline Pati & $-1: 44: 35$ & $12: 13: 35$ & $-24: 08$ & $10: 05$ \\
\hline Bojonegoro & $-1: 41: 04$ & $12: 13: 35$ & $-27: 36$ & $10: 05$ \\
\hline Probolinggo & $-1: 35: 30$ & $12: 13: 35$ & $-32: 52$ & $10: 05$ \\
\hline Banyuwangi & $-1: 31: 11$ & $12: 13: 35$ & $-37: 32$ & $10: 05$ \\
\hline
\end{tabular}

Berdasarkan tabel 4. Nampak pada kolom 5 bahwa saat rasyd al-qiblah harian tanggal 1 Februari terjadi pagi hari dan antara satu daerah dengan daerah lainnya sama tidak ada perbedaan. Yaitu: Musi Rawas, Simpang Pematang, Jepara, Pati, Bojonegoro, Probolingo dan Banyuwangi rasyd alqiblah terjadi pada pukul (10:05). Apabila tabel 2 kolom 5 dikemunikasikan dengan tabel 4. kolom 5 terdapat perbedaan saat rasyd al-qiblah yang signifikan; di mana pada tanggal dan bulan yang sama (1 Februari 2017) antara daerah Limapuluh Koto, Padang, Sorolangun, Tj. Pandan, Belitung dan 
Palembang dengan daerah Musi Rawas, Simpang Pematang, Jepara, Pati, Bojonegoro dan Banyuwangi terdapat perbedaan waktu antara $11-32$ menit.

Perbedaan ini disebabkan berbedanya nilai sudut bantu (p) di mana sudut bantu (p) daerah Limapuluh Koto anatara $\left(-83^{\circ} 30 \mathrm{sd}-89^{\circ} 59^{\prime}\right)$ sedangkan nilai (p) daerah Musi Rawas antara $\left(-72^{\circ} 04^{\prime}\right.$ sd $\left.-83^{\circ} 38^{\prime}\right)$; sedangkan sudut (c-p) hampir tidak ada perbedaan. Dengan kata lain dapat dikatakan bahwa perbadaan saat rasyd al-qiblah antara daerah Limapuluh Koto (tabel 2) dengan Musi Rawas (tabel 4) dipengaruhi oleh letak geografis daerah tersebut dari kakbah, karena posisi matahari sama.

Fenomena yang terdapat pada tabel 2. dan tabel 4. sama dengan fenomena yang terdapat pada tabel 6 dan tabel 8 di bawah ini. Dilihat dari nilai sudut bantu (p) sama-sama berbeda antara satu daerah dengan daerah lainnya, tetapi ditilik dari nilai sudut (c-p) memiliki kesamaan dalam arti semua daerah yang terdapat pada tabel 5 nilai sudut (c-p)nya sama demikian juga nilai sudut (c-p) yang terdapat pada tabel 7. nilai sudut (c-p) dari ke lima daerah tidak ada perbedaan sebagaimana dapat dilihat pada tabel berikut:

Tabel 5. Nilai Sudut Bantu (p), Nilai Sudut (c-p) dan nilai $(C)=[(p)+(c-p)] 15$ Juni

\begin{tabular}{|l|c|c|c|}
\hline \multicolumn{1}{|c|}{ Daerah } & $(\mathrm{p})$ & $(\mathrm{c}-\mathrm{p})$ & $\mathrm{C}=[(\mathrm{p})+(\mathrm{c}-\mathrm{p})]$ \\
\hline \multicolumn{1}{|c|}{1} & 2 & 3 & 4 \\
\hline Metro & $-79^{\circ} 15^{\prime} 37^{\prime \prime}$ & $153^{\circ} 44^{\prime} 11^{\prime \prime}$ & $74^{\circ} 28^{\prime} 34^{\prime \prime}$ \\
\hline Brebes & $-75^{\circ} 26^{\prime} 11^{\prime \prime}$ & $153^{\circ} 33^{\prime} 22^{\prime \prime}$ & $78^{\circ} 07^{\prime} 11 "$ \\
\hline Temanggung & $-74^{\circ} 24^{\prime} 02^{\prime \prime}$ & $153^{\circ} 40^{\prime} 14^{\prime \prime}$ & $79^{\circ} 16^{\prime} 12^{\prime \prime}$ \\
\hline Boyolali & $-73^{\circ} 59^{\prime} 15^{\prime \prime}$ & $153^{\circ} 44^{\prime} 27^{\prime \prime}$ & $79^{\circ} 45^{\prime} 12^{\prime \prime}$ \\
\hline Trenggalek & $-72^{\circ} 48^{\prime} 54^{\prime \prime}$ & $153^{\circ} 45^{\prime} 37^{\prime \prime}$ & $80^{\circ} 56^{\prime} 43^{\prime \prime}$ \\
\hline
\end{tabular}

Nilai sudut (c-p) dari lima daerah yang terdapat pada tabel 4.10 di atas yakni Metro (Lampung), Brebes, Temanggung, Boyolalai (Jawa Tengan) dan Trenggalek di Jawa Timur hampir tidak ada perbedaan walaupun sudut bantu (p) antara satu daeah dengan daerah lainnya berbeda. Nilai sudut (c-p) yang terdapat pada kolom tiga setelah diakumulasikan dengan nilai sudut bantu (p) pada kolom dua menghasilkan nilai (C) sebagaimana terdapat pada kolom empat. Selanjutnya nilai (C) dimasukkan dalam rumus rasyd al-qiblah sebagaimana terdapat pada kolom lima tabel 4.11 di bawah ini.

Tabel 6. Saat Rasyd al-Qiblah 15 Juni

\begin{tabular}{|l|c|c|c|c|}
\hline \multicolumn{1}{|c|}{ Daerah } & C & MP & KWD & C+MP+KWD \\
\hline \multicolumn{1}{|c|}{1} & 2 & 3 & 4 & 5 \\
\hline Metro & $4: 57: 54$ & $12: 00: 29$ & $-01: 12$ & $16: 57$ \\
\hline Brebes & $5: 12: 29$ & $12: 00: 29$ & $-16: 08$ & $16: 57$ \\
\hline Temanggung & $5: 17: 05$ & $12: 00: 29$ & $-20: 32$ & $16: 57$ \\
\hline Boyolali & $5: 19: 01$ & $12: 00: 29$ & $-22: 20$ & $16: 57$ \\
\hline Trenggalek & $5: 2347$ & $12: 00: 29$ & $-26: 48$ & $16: 57$ \\
\hline
\end{tabular}


Dengan memperhatikan tabel 6 akumulasi dari nilai (C) setelah dikonversi ke jam waktu, Meridian Pass (MP), Koreksi Waktu Daerah (KWD) saat rasyd al-qiblah harian Kota Metro, Brebes, Temanggung, Boyolali dan Trenggalek tanggal 15 Juni terjadi pada jam yang sama meski nilai sudut bantu (p)nya berbeda; yakni pukul (16:57). Tabel 7. dan tabel 8. di bawah ini menunjukkan fenomena yang sama dengan tabel 5. dan tabel 6. Hal ini dapat dicermati pada tabel berikut:

Tabel 7. Nilai Sudut Bantu (p), Nilai Sudut (c-p) dan nilai $(C)=[(p)+(c-p)] 15$ Juni

\begin{tabular}{|c|c|c|c|}
\hline Daerah & (p) & (c-p) & $\mathrm{C}=[(\mathrm{p})+(\mathrm{c}-\mathrm{p})]$ \\
\hline 1 & 2 & 3 & 4 \\
\hline Lemong & $-79^{\circ} 47^{\prime} 41^{\prime \prime}$ & $152^{\circ} 11^{\prime} 14^{\prime \prime}$ & $72^{\circ} 23^{\prime} 33^{\prime \prime}$ \\
\hline Anyer & $-77^{\circ} 26^{\prime} 56^{\prime \prime}$ & $152^{\circ} 04^{\prime} 03^{\prime \prime}$ & $79^{\circ} 37^{\prime} 07^{\prime \prime}$ \\
\hline Serang & $-77^{\circ} 15^{\prime} 49^{\prime \prime}$ & $152^{\circ} 08^{\prime} 09^{\prime \prime}$ & $79^{\circ} 52^{\prime} 20^{\prime \prime}$ \\
\hline Gombong & $-74^{\circ} 05^{\prime} 06^{\prime \prime}$ & $152^{\circ} 19^{\prime} 09^{\prime \prime}$ & $78^{\circ} 14^{\prime} 03^{\prime \prime}$ \\
\hline Kebumen & $-73^{\circ} 53^{\prime} 50^{\prime \prime}$ & $152^{\circ} 21^{\prime} 41^{\prime \prime}$ & $78^{\circ} 27^{\prime} 51^{\prime \prime}$ \\
\hline $\begin{array}{l}\text { Kulon } \\
\text { Progo }\end{array}$ & $-73^{\circ} 24^{\prime} 06^{\prime \prime}$ & $152^{\circ} 16^{\prime} 24^{\prime \prime}$ & $78^{\circ} 52^{\prime} 18^{\prime \prime}$ \\
\hline
\end{tabular}

Dengan mencermati tabel 7 di bawah ini, Nampak pada kolom dua nilai sudut bantu (p) bervariasi sementara pada kolom tiga nilai sudut (c-p) dapat dikatakan sama. Setelah nilai sudut bantu (p) diakumulasi dengan nilai sudut (c-p) menghasilkan nilai (C). sebagaimana pada kolom empat. Nilai (C) yang terdapat pada kolom empat tabel 7. selanjutnya diakumulasikan dengan rumus rasyd al-qiblah yang terdapat pada kolom lima tabel 8. di bawah ini:

Tabel 8. Saat Rasyd al-Qiblah 15 Juni

\begin{tabular}{|l|c|c|c|c|}
\hline \multicolumn{1}{|c|}{ Daerah } & C & MP & KWD & C+MP+KWD \\
\hline \multicolumn{1}{|c|}{1} & 2 & 3 & 4 & 5 \\
\hline Lemong & $4: 49: 34$ & $12: 00: 29$ & $0: 05: 24$ & $16: 55$ \\
\hline Anyer & $4: 58: 28$ & $12: 00: 29$ & $-0: 03: 52$ & $16: 55$ \\
\hline Serang & $4: 59: 29$ & $12: 00: 29$ & $-0: 04: 36$ & $16: 55$ \\
\hline Gombong & $5: 12: 56$ & $12: 00: 29$ & $-0: 18: 04$ & $16: 55$ \\
\hline Kebumen & $5: 13: 51$ & $12: 00: 29$ & $-0: 19: 08$ & $16: 55$ \\
\hline Kulon Progo & $5: 15: 29$ & $12: 00: 29$ & $-0: 20: 28$ & $16: 55$ \\
\hline
\end{tabular}

Setelah nilai sudut (c-p) pada tabel 7. dikonversi dengan jam waktu dan dimasukkan dalam rumus rasyd al-qiblah pada tabel 8. menghasilkan saat rasyd al-qiblah yang sama pada tanggal yang sama (15 Juni) untuk derah Lemong, Anyer, Serang, Gombong, Kebumen dan Kulonprogo pukul (16:55) sebagaimana terdapat pada kolom lima tabel 8.

Berdasarkan paparan di atas baik dilihat dari nilai sudut bantu (p) yang terdapat pada tabel 5 maupun tabel 7 memiliki nilai besaran yang berbedabeda, tetapi dilihat dari nilai sudut (c-p) besaran nilainya sama dan setelah 
diakumulasikan dengan nilai sudut bantu (p) nilai (C) menjadi besar. Setelah nilai (C) diakumulasikan dengan MP dan KWD saat rasyd al-qiblah terjadi sore hari, yaitu pukul (16:57) untuk daerah yang terdapat pada tabel 6 dan pukul (16:55) untuk daerah yang terdapat pada tabel 8.

Perbedaan saat rasyd al-qiblah antara daerah yang terdapat pada tabel 2 dan tabel 4 dengan saat rasyd al-qiblah yang terdapat pada tabel 6 dan tabel 8 disebabkan perbedaan nilai sudut (c-p) sementara nilai sudut (c-p) dipengaruhi oleh posisi matahari dari kakbah. Dengan demikian perbedaan saat rasyd alqiblah antara yang tertera pada pada tabel 2 dan tabel 4 (pagi hari) dengan saat rasyd al-qiblah yang terdapat pada tabel 6 dan tabel 8 (sore hari) dipengaruhi oleh posisi matahari dari kakbah.

Rasyd al-qiblah yang terdapat pada tabel 2 dan 4 terjadi pada 1 Februari 2017 dengan posisi matahari (38 $\left.27^{\prime} 41^{\prime \prime}\right)$ di Selatan kakbah, sementara rasyd al-qiblah yang tertera pada pada tabel 6 dan tabel 8 terjadi pada tanggal 15 Juni 2017 dengan posisi matahari (01 $\left.53^{\prime} 42^{\prime \prime}\right)$ di Utara kakbah. Dengan demikian dapat dikatakan bahwa ketika posisi matahari berada di sekitar kakbah peristiwa rasyd al-qiblah akan terjadi sore hari untuk wilayah Indonesia. Sebaliknya pada saat posisi matahri jauh di Selatan kakabah (garis balik Selatan) peristiwa rasyd al-qiblah akan terjadi pagi hari dan pada saat posisi matahari berada di sekitar khatuslistiwa peristiwa rasyd al-qiblah akan terjadi siang hari. Hal ini dapat dibuktikan melalui sajian tabel 9, 10, 11 dan tabel 12 sebagai berikut:

Tabel 9. Nilai Sudut Bantu (p), Nilai Sudut (c-p) dan nilai $(C)=[(p)+(c-p)] 1$ Desember

\begin{tabular}{|l|c|c|c|}
\hline \multicolumn{1}{|c|}{ Daerah } & $(\mathrm{p})$ & $(\mathrm{c}-\mathrm{p})$ & $\mathrm{C}=[(\mathrm{p})+(\mathrm{c}-\mathrm{p})]$ \\
\hline \multicolumn{1}{|c|}{1} & 2 & 3 & 4 \\
\hline Gayabaru & $-79^{\circ} 54^{\prime} 07^{\prime \prime}$ & $33^{\circ} 41^{\prime} 37^{\prime \prime}$ & $-46^{\circ} 12^{\prime} 30^{\prime \prime}$ \\
\hline Ponorogo & $-73^{\circ} 09^{\prime} 33^{\prime \prime}$ & $33^{\circ} 28^{\prime} 04^{\prime \prime}$ & $-39^{\circ} 41^{\prime} 29^{\prime \prime}$ \\
\hline Malang & $-72^{\circ} 50^{\prime} 23^{\prime \prime}$ & $33^{\circ} 36^{\prime} 35^{\prime \prime}$ & $-39^{\circ} 13^{\prime} 48^{\prime \prime}$ \\
\hline Tulung Agung & $-72^{\circ} 50^{\prime} 38^{\prime \prime}$ & $33^{\circ} 22^{\prime} 27^{\prime \prime}$ & $-39^{\circ} 28^{\prime} 11^{\prime \prime}$ \\
\hline Surakarta & $-73^{\circ} 53^{\prime} 08^{\prime \prime}$ & $33^{\circ} 24^{\prime} 33^{\prime \prime}$ & $-40^{\circ} 28^{\prime} 35^{\prime \prime}$ \\
\hline
\end{tabular}

Tabel 10. Saat Rasyd al-Qiblah 1 Desember

\begin{tabular}{|l|c|c|c|c|}
\hline \multicolumn{1}{|c|}{ Daerah } & C & MP & KWD & C+MP+KWD \\
\hline \multicolumn{1}{|c|}{1} & 2 & 3 & 4 & 5 \\
\hline Gayabaru & $-3: 04: 50$ & $11: 49: 00$ & $-0: 02: 28$ & $8: 42$ \\
\hline Ponorogo & $-2: 38: 46$ & $11: 49: 00$ & $-0: 26: 04$ & $8: 44$ \\
\hline Malang & $-2: 36: 55$ & $11: 49: 00$ & $-0: 30: 28$ & $8: 42$ \\
\hline Tulung Agung & $-2: 37: 53$ & $11: 49: 00$ & $-0: 27: 36$ & $8: 44$ \\
\hline Surakarta & $-2: 41: 54$ & $11: 49: 00$ & $-0: 21: 45$ & $8: 45$ \\
\hline
\end{tabular}

Melalui tabel 9 dapat dipahami bahwa nilai sudut bantu (p) antara satu daerah dengan darah lainnya berbeda-beda. Sama halnya dengan nilai sudut bantu yang terdapat pada tabel 11 juga berbeda-berbeda, sementara nilai (c-p) 
dari daerah yang terdapat pada tabel 10 dan tabel 12 ada perbedaan tapi kurang signifikan. Setelah nilai (C) diakumulasikan dengan nilai MP dan KWD, maka diperoleh saat rasyd al-qiblah terjadi pagi hari antara pukul (08:42-08:45) untuk daerah yang terdapat pada tabel 11 dan antara pukul (08:29-08:31) untuk daerah yang terdapat pada tabel 12 .

Tabel 11. Nilai Sudut Bantu (p), Nilai Sudut (c-p) dan nilai $(C)=[(p)+(c-p)] 1$ Desember

\begin{tabular}{|l|c|c|c|}
\hline \multicolumn{1}{|c|}{ Daerah } & $(\mathrm{p})$ & $(\mathrm{c}-\mathrm{p})$ & $\mathrm{C}=[(\mathrm{p})+(\mathrm{c}-\mathrm{p})]$ \\
\hline \multicolumn{1}{c|}{} & 2 & 3 & 4 \\
\hline Musi Rawas & $-83^{\circ} 37^{\prime} 53^{\prime \prime}$ & $31^{\circ} 32^{\prime} 47^{\prime \prime}$ & $-52^{\circ} 05^{\prime} 06^{\prime \prime}$ \\
\hline Sp. Pematang & $-81^{\circ} 11^{\prime} 20^{\prime \prime}$ & $31^{\circ} 33^{\prime} 12^{\prime \prime}$ & $-49^{\circ} 38^{\prime} 08^{\prime \prime}$ \\
\hline Jepara & $-75^{\circ} 45^{\prime} 00^{\prime \prime}$ & $31^{\circ} 55^{\prime} 31^{\prime \prime}$ & $-43^{\circ} 49^{\prime} 29^{\prime \prime}$ \\
\hline Pati & $-75^{\circ} 24^{\prime} 32^{\prime \prime}$ & $31^{\circ} 31^{\prime} 36^{\prime \prime}$ & $-43^{\circ} 52^{\prime} 56^{\prime \prime}$ \\
\hline Bojonegoro & $-74^{\circ} 27^{\prime} 05^{\prime \prime}$ & $31^{\circ} 23^{\prime} 43^{\prime \prime}$ & $-43^{\circ} 03^{\prime} 22^{\prime \prime}$ \\
\hline Probolinggo & $-73^{\circ} 10^{\prime} 28^{\prime \prime}$ & $31^{\circ} 36^{\prime} 45^{\prime \prime}$ & $-41^{\circ} 33^{\prime} 43^{\prime \prime}$ \\
\hline Banyuwangi & $-72^{\circ} 03^{\prime} 54^{\prime \prime}$ & $31^{\circ} 33^{\prime} 26^{\prime \prime}$ & $-40^{\circ} 30^{\prime} 28^{\prime \prime}$ \\
\hline
\end{tabular}

Tabel 12. Saat Rasyd al-Qiblah 1 Desember

\begin{tabular}{|l|c|c|c|c|}
\hline \multicolumn{1}{|c|}{ Daerah } & C & MP & KWD & C+MP+KWD \\
\hline \multicolumn{1}{|c|}{1} & 2 & 3 & 4 & 5 \\
\hline Musi Rawas & $-3: 28: 20$ & $11: 49: 00$ & $08: 48$ & $8: 29$ \\
\hline Sp. Pematang & $-3: 18: 33$ & $11: 49: 00$ & $-00: 52$ & $8: 29$ \\
\hline Jepara & $-2: 55: 18$ & $11: 49: 00$ & $-22: 36$ & $8: 30$ \\
\hline Pati & $-2: 59: 32$ & $11: 49: 00$ & $-24: 08$ & $8: 31$ \\
\hline Bojonegoro & $-2: 52: 13$ & $11: 49: 00$ & $-27: 36$ & $8: 29$ \\
\hline Probolinggo & $-2: 46: 15$ & $11: 49: 00$ & $-32: 52$ & $8: 30$ \\
\hline Banyuwangi & $-2: 42: 02$ & $11: 49: 00$ & $-37: 32$ & $8: 29$ \\
\hline
\end{tabular}

Dengan memperhatikan saat rasyd al-qiblah sebagaimana terdapat pada tabel 10 dan tabel 12 ternyata terdapat perbedaan waktu antara 13-14 menit. Perbedaan ini disebabkan perbedaan letak geograis antara satu daerah dengan daerah lainnya dari kakbah. Jika dibandingkan saat rasyd al-qiblah antara yang terdapat pada tabel 2 dan tabel 4 (1 Februari 2017) rata-rata pukul (09:40) dan pukul (10:05), tabel 6 dan tabel 8 (15 Juni 2017) rata-rata pukul (16:57) dan pukul (16:55), sedangkan tabel 10 dan tabel 12 (1 Desember 2017) rata-rata pukul (08:43) dan pukul (08:30).

Perbedaan saat terjadi rasyd al-qiblah sebagaimana dipaparkan di atas yang sangat signifikan dari 1 Februari pukul (09:40 dan 10:05) ke 15 Juni pukul (16:57 dan 16:55) dan 1 Desember pukul (08:43 dan 08:30) dipengaruhi oleh psoisi matahari dari kakbah. Posisi matahari dari kakbah tanggal 1 Februari 2017 (38 $\left.27^{\prime} 41^{\prime \prime}\right)$ di Selatan kakbah, 15 Juni 2017 (1 $\left.{ }^{\circ} 53^{\prime} 42^{\prime \prime}\right)$ di Utara kakbah dan 1 Desember 2017 (42 54'26") di Selatan kakbah. 
Untuk melihat perbedaan rasyd al-qiblah di berbagai daerah bulan Juni dan bulan Desember peneliti sajikan melalui tabel 13, 14,15 dan tabel 16. sebagai berikut:

Tabel 13. Nilai (c-p) Berbagai Daerah di Indonesia Tanggal 15 Juni 2017

\begin{tabular}{|c|c|c|c|}
\hline Daerah & Sudut (p) & Sudut (c-p) & $C=[(p)+(c-p)]$ \\
\hline 1 & 2 & 3 & 4 \\
\hline 50 Koto & $-89^{\circ} 57^{\prime} 47^{\prime \prime}$ & $162^{\circ} 46^{\prime} 38^{\prime \prime}$ & $72^{\circ} 48^{\prime} 51^{\prime \prime}$ \\
\hline Padang & $-87^{\circ} 55^{\prime} 57^{\prime \prime}$ & $159^{\circ} 38^{\prime} 00^{\prime \prime}$ & $71^{\circ} 42^{\prime} 03^{\prime \prime}$ \\
\hline Sorolangun & $-85^{\circ} 13^{\prime} 05^{\prime \prime}$ & $159^{\circ} 14^{\prime} 18^{\prime \prime}$ & $74^{\circ} 01^{\prime} 13^{\prime \prime}$ \\
\hline Tj. Pandan & $-83^{\circ} 46^{\prime} 09^{\prime \prime}$ & $165^{\circ} 24^{\prime} 49^{\prime \prime}$ & $81^{\circ} 38^{\prime} 40^{\prime \prime}$ \\
\hline Belitung & $-83^{\circ} 35^{\prime} 17^{\prime \prime}$ & $165^{\circ} 09^{\prime} 17^{\prime \prime}$ & $81^{\circ} 34^{\prime} 00^{\prime \prime}$ \\
\hline Palembang & $-83^{\circ} 29^{\prime} 41^{\prime \prime}$ & $159^{\circ} 30^{\prime} 34^{\prime \prime}$ & $76^{\circ} 00^{\prime} 53^{\prime \prime}$ \\
\hline Musi Rawas & $-83^{\circ} 37^{\prime} 53^{\prime \prime}$ & $156^{\circ} 30^{\prime} 37^{\prime \prime}$ & $72^{\circ} 52^{\prime} 44^{\prime \prime}$ \\
\hline Sp. Pematang & $-81^{\circ} 11^{\prime} 20^{\prime \prime}$ & $156^{\circ} 30^{\prime} 02^{\prime \prime}$ & $75^{\circ} 18^{\prime} 42^{\prime \prime}$ \\
\hline Jepara & $-75^{\circ} 45^{\prime} 00^{\prime \prime}$ & $156^{\circ} 27^{\prime} 01^{\prime \prime}$ & $80^{\circ} 42^{\prime} 01^{\prime \prime}$ \\
\hline Pati & $-75^{\circ} 24^{\prime} 32^{\prime \prime}$ & $156^{\circ} 30^{\prime} 47^{\prime \prime}$ & $81^{\circ} 06^{\prime} 15^{\prime \prime}$ \\
\hline Bojonegoro & $-74^{\circ} 27^{\prime} 05^{\prime \prime}$ & $156^{\circ} 43^{\prime} 28^{\prime \prime}$ & $82^{\circ} 16^{\prime} 23^{\prime \prime}$ \\
\hline Purbolinggo & $-73^{\circ} 10^{\prime} 28^{\prime \prime}$ & $156^{\circ} 25^{\prime} 02^{\prime \prime}$ & $83^{\circ} 14^{\prime} 34^{\prime \prime}$ \\
\hline Banyuwangi & $-72^{\circ} 03^{\prime} 54^{\prime \prime}$ & $156^{\circ} 29^{\prime} 44^{\prime \prime}$ & $84^{\circ} 25^{\prime} 50^{\prime \prime}$ \\
\hline Metro & $-79^{\circ} 15^{\prime} 37^{\prime \prime}$ & $153^{\circ} 44^{\prime} 11^{\prime \prime}$ & $74^{\circ} 28^{\prime} 34^{\prime \prime}$ \\
\hline Brebes & $-75^{\circ} 26^{\prime} 11^{\prime \prime}$ & $153^{\circ} 33^{\prime} 22^{\prime \prime}$ & $78^{\circ} 07^{\prime} 11^{\prime \prime}$ \\
\hline Temanggung & $-74^{\circ} 24^{\prime} 02^{\prime \prime}$ & $153^{\circ} 40^{\prime} 14^{\prime \prime}$ & $79^{\circ} 16^{\prime} 12^{\prime \prime}$ \\
\hline Boyolali & $-73^{\circ} 59^{\prime} 15^{\prime \prime}$ & $153^{\circ} 44^{\prime} 27^{\prime \prime}$ & $79^{\circ} 45^{\prime} 12^{\prime \prime}$ \\
\hline Trenggalek & $-72^{\circ} 48^{\prime} 54^{\prime \prime}$ & $153^{\circ} 45^{\prime} 37^{\prime \prime}$ & $80^{\circ} 56^{\prime} 43^{\prime \prime}$ \\
\hline Lemong & $-79^{\circ} 47^{\prime} 41^{\prime \prime}$ & $152^{\circ} 11^{\prime} 14^{\prime \prime}$ & $72^{\circ} 23^{\prime} 33^{\prime \prime}$ \\
\hline Anyer & $-77^{\circ} 26^{\prime} 56^{\prime \prime}$ & $152^{\circ} 04^{\prime} 03^{\prime \prime}$ & 79॰37'07" \\
\hline Serang & $-77^{\circ} 15^{\prime} 49^{\prime \prime}$ & $152^{\circ} 08^{\prime} 09^{\prime \prime}$ & $79^{\circ} 52^{\prime} 20^{\prime \prime}$ \\
\hline Gombong & $-74^{\circ} 05^{\prime} 06^{\prime \prime}$ & $152^{\circ} 19^{\prime} 09^{\prime \prime}$ & $78^{\circ} 14^{\prime} 03^{\prime \prime}$ \\
\hline Kebumen & $-73^{\circ} 53^{\prime} 50^{\prime \prime}$ & $152^{\circ} 21^{\prime} 41^{\prime \prime}$ & $78^{\circ} 27^{\prime} 51^{\prime \prime}$ \\
\hline Kulon Progo & $-73^{\circ} 24^{\prime} 06^{\prime \prime}$ & $152^{\circ} 16^{\prime} 24^{\prime \prime}$ & $78^{\circ} 52^{\prime} 18^{\prime \prime}$ \\
\hline Gayabaru & $-79^{\circ} 54^{\prime} 07^{\prime \prime}$ & $156^{\circ} 18^{\prime} 11^{\prime \prime}$ & $76^{\circ} 24^{\prime} 04^{\prime \prime}$ \\
\hline Ponorogo & $-73^{\circ} 09^{\prime} 33^{\prime \prime}$ & $153^{\circ} 51^{\prime} 45^{\prime \prime}$ & $80^{\circ} 42^{\prime} 12^{\prime \prime}$ \\
\hline Malang & $-72^{\circ} 50^{\prime} 23^{\prime \prime}$ & $155^{\circ} 01^{\prime} 47^{\prime \prime}$ & $82^{\circ} 11^{\prime} 24^{\prime \prime}$ \\
\hline Tulung Ag & $-72^{\circ} 50^{\prime} 38^{\prime \prime}$ & $153^{\circ} 59^{\prime} 26^{\prime \prime}$ & $81^{\circ} 08^{\prime} 48^{\prime \prime}$ \\
\hline Surakarta & $-73^{\circ} 53^{\prime} 08^{\prime \prime}$ & $153^{\circ} 56^{\prime} 30^{\prime \prime}$ & $80^{\circ} 03^{\prime} 22^{\prime \prime}$ \\
\hline
\end{tabular}

Berdasarkan tabel 13 dari 29 daerah sampel yang letak geografisnya di Selatan khatulistiwa antara lintang $\left(-00^{\circ} 01^{\prime \prime}\right)$ sampai $\left(-8^{\circ} 14^{\prime}\right)$ dengan bujur antara $\left(100^{\circ} 34^{\prime}\right)$ sampai $\left(114^{\circ} 23^{\prime}\right)$ Timur. Letak geografis dari kakbah antara $\left(21^{\circ} 26^{\prime}\right)$ sampai $\left(29^{\circ} 39^{\prime}\right)$ di Selatan kakbah, sementara posisi matahari tanggal 1 Febuari 2017 (38 $\left.27^{\prime} 41^{\prime \prime}\right)$ di Selatan kakbah, tanggal 15 Juni 2017 (153'42") 
di Utara kakbah dan tanggal 1 Desember 2017 (42 54'26") di Selatan kakbah. Sudut bantu (p) berkisar (-72 03'54") Banyuwangi di Jawa Timur sampai (8903'54") Limapuluh Koto di Sumatera Barat.

Dengan posisi yang beragam baik posisi matahari maupun posisi letak geografis daerah dari kakbah akan mempengaruhi saat terjadinya rasyd alqiblah di berbagai daerah di Indonesia. Pengaruh posisi matahari dari kakbah terhadap rasyd al-qiblah di Indonesia. Semakin dekat matahari dengan kakbah (15 Juni) semakin besar sudut (c-p) rasyd al-qiblah akan terjadi sore hari, semakin jauh dari kakbah sudut (c-p) semakin kecil peristiwa rasyd al-qiblah akan terjadi pagi hari dan pada posisi matahari berada di sekitar khatulistiwa (jarak sedang) dari kakbah rasyd al-qiblah akan terjadi siang hari. Hal ini dapat cermati melalui tabel 4.19 dan 4.21. sebagai berikut:

Tabel 14. Rasyd al-Qiblah Berbagai Daerah di Indonesia Tanggal 15 Juni 2017

\begin{tabular}{|l|c|c|c|c|}
\hline \multicolumn{1}{|c|}{ Daerah } & Nilai (C) & MP & KWD & C+MP+KWD \\
\hline 50 Koto & 2 & 3 & 4 & 5 \\
\hline Padang & $4: 51: 15$ & $12: 00: 29$ & $0: 17: 44$ & $17: 09$ \\
\hline Sorolangun & $4: 46: 48$ & $12: 00: 29$ & $0: 18: 32$ & $17: 06$ \\
\hline Tj. Pandan & $5: 26: 35$ & $12: 00: 29$ & $0: 08: 00$ & $17: 05$ \\
\hline Belitung & $5: 26: 16$ & $12: 00: 29$ & $-0: 11: 16$ & $17: 16$ \\
\hline Palembang & $5: 04: 04$ & $12: 00: 29$ & $-0: 11: 40$ & $17: 16$ \\
\hline Musi Rawas & $4: 51: 31$ & $12: 00: 29$ & $08: 48$ & $17: 05$ \\
\hline Sp. Pematang & $5: 01: 08$ & $12: 00: 29$ & $-00: 52$ & $17: 01$ \\
\hline Jepara & $5: 22: 48$ & $12: 00: 29$ & $-22: 36$ & $17: 01$ \\
\hline Pati & $5: 24: 25$ & $12: 00: 29$ & $-24: 08$ & $17: 01$ \\
\hline Bojonegoro & $5: 29: 06$ & $12: 00: 29$ & $-27: 36$ & $17: 01$ \\
\hline Purbolinggo & $5: 32: 58$ & $12: 00: 29$ & $-32: 52$ & $17: 01$ \\
\hline Banyuwangi & $5: 37: 43$ & $12: 00: 29$ & $-37: 32$ & $17: 01$ \\
\hline Metro & $4: 57: 54$ & $12: 00: 29$ & $-01: 12$ & $16: 57$ \\
\hline Brebes & $5: 12: 29$ & $12: 00: 29$ & $-16: 08$ & $16: 57$ \\
\hline Temanggung & $5: 17: 05$ & $12: 00: 29$ & $-20: 32$ & $16: 57$ \\
\hline Boyolali & $5: 19: 01$ & $12: 00: 29$ & $-22: 20$ & $16: 57$ \\
\hline Trenggalek & $5: 2347$ & $12: 00: 29$ & $-26: 48$ & $16: 57$ \\
\hline Lemong & $4: 49: 34$ & $12: 00: 29$ & $0: 05: 24$ & $16: 55$ \\
\hline Anyer & $4: 58: 28$ & $12: 00: 29$ & $-0: 03: 52$ & $16: 55$ \\
\hline Serang & $4: 59: 29$ & $12: 00: 29$ & $-0: 04: 36$ & $16: 55$ \\
\hline Gombong & $5: 12: 56$ & $12: 00: 29$ & $-0: 18: 04$ & $16: 55$ \\
\hline Kebumen & $5: 13: 51$ & $12: 00: 29$ & $-0: 19: 08$ & $16: 55$ \\
\hline Kulon Progo & $5: 15: 29$ & $12: 00: 29$ & $-0: 20: 28$ & $16: 55$ \\
\hline
\end{tabular}


Pada tabel 14 posisi matahari berada di sekitar kakbah dengan jarak $\left(1^{\circ} 53^{\prime} 42^{\prime \prime}\right)$ di Utara kakbah, saat peristiwa rasyd al-qiblah mulai dari daerah yang letak geografisnya dekat dengan kakbah seperti Limapuluh Koto dengan jarak $\left(21^{\circ} 26^{\prime}\right)$ di Selatan kakbah sampai Banyuwangi dengan jarak $\left(29^{\circ} 39^{\prime}\right)$ di Selatan kakbah sebanyak 29 daerah sampel terjadi sore hari antara pukul (17:16) dareah $\mathrm{Tj}$. Pandan dan Belitung sampai pukul (16:55) daerah Kulonprogo Daear Istiwa Yogyakarta.

Tabel 15. Nilai (c-p) Berbagai Daerah di Indonesia 15 Desember 2017

\begin{tabular}{|c|c|c|c|}
\hline Daerah & Sudut (p) & Sudut (c-p) & $\mathrm{C}=[(\mathrm{p})+(\mathrm{c}-\mathrm{p})$ \\
\hline 1 & 2 & 3 & 4 \\
\hline 50 Koto & $-89^{\circ} 57^{\prime} 47^{\prime \prime}$ & $17^{\circ} 36^{\prime} 16^{\prime \prime}$ & $-72^{\circ} 21^{\prime} 31^{\prime \prime}$ \\
\hline Padang & $-87^{\circ} 55^{\prime} 57^{\prime \prime}$ & $20^{\circ} 41^{\prime} 12^{\prime \prime}$ & $-65^{\circ} 14^{\prime} 45^{\prime \prime}$ \\
\hline Sorolangun & $-85^{\circ} 13^{\prime} 05^{\prime \prime}$ & $21^{\circ} 04^{\prime} 31^{\prime \prime}$ & $-64^{\circ} 08^{\prime} 34^{\prime \prime}$ \\
\hline Tj. Pandan & $-83^{\circ} 46^{\prime} 09^{\prime \prime}$ & $15^{\circ} 02^{\prime} 27^{\prime \prime}$ & $-68^{\circ} 43^{\prime} 42^{\prime \prime}$ \\
\hline Belitung & $-83^{\circ} 35^{\prime} 17^{\prime \prime}$ & $15^{\circ} 17^{\prime} 25^{\prime \prime}$ & $-68^{\circ} 17^{\prime} 52^{\prime \prime}$ \\
\hline Palembang & $-83^{\circ} 29^{\prime} 41^{\prime \prime}$ & $20^{\circ} 48^{\prime} 30^{\prime \prime}$ & $-62^{\circ} 41^{\prime} 11^{\prime \prime}$ \\
\hline Musi Rawas & $-83^{\circ} 37^{\prime} 53^{\prime \prime}$ & $23^{\circ} 45^{\prime} 48^{\prime \prime}$ & $-59^{\circ} 52^{\prime} 05^{\prime \prime}$ \\
\hline Sp. Pem & $-81^{\circ} 11^{\prime} 20^{\prime \prime}$ & $23^{\circ} 46^{\prime} 23^{\prime \prime}$ & $-57^{\circ} 24^{\prime} 57^{\prime \prime}$ \\
\hline Jepara & $-75^{\circ} 45^{\prime} 00^{\prime \prime}$ & $23^{\circ} 49^{\prime} 22^{\prime \prime}$ & $-51^{\circ} 55^{\prime} 38^{\prime \prime}$ \\
\hline Pati & $-75^{\circ} 24^{\prime} 32^{\prime \prime}$ & $23^{\circ} 45^{\prime} 39^{\prime \prime}$ & $-51^{\circ} 38^{\prime} 53^{\prime \prime}$ \\
\hline Bojonegoro & $-74^{\circ} 27^{\prime} 05^{\prime \prime}$ & $23^{\circ} 33^{\prime} 07^{\prime \prime}$ & $-50^{\circ} 53^{\prime} 58^{\prime \prime}$ \\
\hline Purbolin & $-73^{\circ} 10^{\prime} 28^{\prime \prime}$ & $23^{\circ} 51^{\prime} 20^{\prime \prime}$ & $-49^{\circ} 19^{\prime} 08^{\prime \prime}$ \\
\hline Banyuw & $-72^{\circ} 03^{\prime} 54^{\prime \prime}$ & $23^{\circ} 46^{\prime} 42^{\prime \prime}$ & $-48^{\circ} 17^{\prime} 12^{\prime \prime}$ \\
\hline Metro & $-79^{\circ} 15^{\prime} 37^{\prime \prime}$ & $26^{\circ} 30^{\prime} 19^{\prime \prime}$ & $-52^{\circ} 45^{\prime} 18^{\prime \prime}$ \\
\hline Brebes & $-75^{\circ} 26^{\prime} 11^{\prime \prime}$ & $26^{\circ} 41^{\prime} 00^{\prime \prime}$ & $-48^{\circ} 45^{\prime} 11^{\prime \prime}$ \\
\hline Temang & $-74^{\circ} 24^{\prime} 02^{\prime \prime}$ & $26^{\circ} 34^{\prime} 13^{\prime \prime}$ & $-47^{\circ} 49^{\prime} 49^{\prime \prime}$ \\
\hline Boyolali & $-73^{\circ} 59^{\prime} 15^{\prime \prime}$ & $26^{\circ} 30^{\prime} 02^{\prime \prime}$ & $-47^{\circ} 29^{\prime} 13^{\prime \prime}$ \\
\hline Trenggalek & $-72^{\circ} 48^{\prime} 54^{\prime \prime}$ & $26^{\circ} 33^{\prime} 00^{\prime \prime}$ & $-46^{\circ} 15^{\prime} 54^{\prime \prime}$ \\
\hline Lemong & $-79^{\circ} 47^{\prime} 41^{\prime \prime}$ & $28^{\circ} 38^{\prime} 10^{\prime \prime}$ & $-51^{\circ} 09^{\prime} 31^{\prime \prime}$ \\
\hline Anyer & $-77^{\circ} 26^{\prime} 56^{\prime \prime}$ & $28^{\circ} 41^{\prime} 57^{\prime \prime}$ & $-48^{\circ} 44^{\prime} 59^{\prime \prime}$ \\
\hline Serang & $-77^{\circ} 15^{\prime} 49^{\prime \prime}$ & $28^{\circ} 40^{\prime} 60^{\prime \prime}$ & $-48^{\circ} 39^{\prime} 49^{\prime \prime}$ \\
\hline Gombong & $-74^{\circ} 05^{\prime} 06^{\prime \prime}$ & $28^{\circ} 30^{\prime} 27^{\prime \prime}$ & $-48^{\circ} 39^{\prime} 39^{\prime \prime}$ \\
\hline Kebumen & $-73^{\circ} 53^{\prime} 50^{\prime \prime}$ & $28^{\circ} 27^{\prime} 14^{\prime \prime}$ & $-45^{\circ} 26^{\prime} 36^{\prime \prime}$ \\
\hline Kulon Progo & $-73^{\circ} 24^{\prime} 06^{\prime \prime}$ & $28^{\circ} 33^{\prime} 00^{\prime \prime}$ & $-44^{\circ} 51^{\prime} 06^{\prime \prime}$ \\
\hline Gayabaru & $-79^{\circ} 54^{\prime} 07^{\prime \prime}$ & $23^{\circ} 58^{\prime} 05^{\prime \prime}$ & $-55^{\circ} 56^{\prime} 02^{\prime \prime}$ \\
\hline Ponorogo & $-73^{\circ} 09^{\prime} 33^{\prime \prime}$ & $26^{\circ} 22^{\prime} 49^{\prime \prime}$ & $-46^{\circ} 46^{\prime} 44^{\prime \prime}$ \\
\hline Malang & $-72^{\circ} 50^{\prime} 23^{\prime \prime}$ & $25^{\circ} 13^{\prime} 34^{\prime \prime}$ & $-47^{\circ} 36^{\prime} 49^{\prime \prime}$ \\
\hline Tulung Ag & $-72^{\circ} 50^{\prime} 38^{\prime \prime}$ & $26^{\circ} 15^{\prime} 19^{\prime \prime}$ & $-46^{\circ} 35^{\prime} 19^{\prime \prime}$ \\
\hline Surakarta & $-73^{\circ} 53^{\prime} 08^{\prime \prime}$ & $26^{\circ} 18^{\prime} 07^{\prime \prime}$ & $-47^{\circ} 35^{\prime} 01^{\prime \prime}$ \\
\hline
\end{tabular}

Tabel 16. Rasyd al-Qiblah Berbagai Daerah 
di IndonesiaTanggal 15 Desember 2017

\begin{tabular}{|l|c|c|c|c|}
\hline \multicolumn{1}{|c|}{ Daerah } & Nilai (C) & MP & KWD & C+MP+KWD \\
\hline \multicolumn{1}{|c|}{1} & 2 & 3 & 4 & 5 \\
\hline 50 Koto & $-4: 49: 26$ & $11: 55: 06$ & $0: 17: 44$ & $7: 23$ \\
\hline Padang & $-4: 20: 59$ & $11: 55: 06$ & $0: 18: 32$ & $7: 53$ \\
\hline Sorolangun & $-4: 16: 34$ & $11: 55: 06$ & $0: 08: 00$ & $7: 47$ \\
\hline Tj. Pandan & $-4: 31: 54$ & $11: 55: 06$ & $-0: 11: 16$ & $7: 12$ \\
\hline Belitung & $-4: 33: 11$ & $11: 55: 06$ & $-0: 11: 40$ & $7: 10$ \\
\hline Palembang & $-4: 10: 45$ & $11: 55: 06$ & $0: 00: 36$ & $7: 45$ \\
\hline Musi Rawas & $-3: 59: 20$ & $11: 5506$ & $08: 48$ & $8: 04$ \\
\hline Sp. Pematang & $-3: 49: 40$ & $11: 5506$ & $-00: 52$ & $8: 05$ \\
\hline Jepara & $-3: 27: 43$ & $11: 5506$ & $-22: 36$ & $8: 05$ \\
\hline Pati & $-3: 26: 36$ & $11: 5506$ & $-24: 08$ & $8: 04$ \\
\hline Bojonegoro & $-3: 23: 36$ & $11: 5506$ & $-27: 36$ & $8: 04$ \\
\hline Purbolinggo & $-3: 17: 17$ & $11: 5506$ & $-32: 52$ & $8: 05$ \\
\hline Banyuwangi & $-3: 13: 09$ & $11: 5506$ & $-37: 32$ & $8: 04$ \\
\hline Metro & $-3: 31: 01$ & $11: 55: 06$ & $-01: 12$ & $8: 23$ \\
\hline Brebes & $-3: 15: 01$ & $11: 55: 06$ & $-16: 08$ & $8: 24$ \\
\hline Temanggung & $-3: 11: 19$ & $11: 55: 06$ & $-20: 32$ & $8: 23$ \\
\hline Boyolali & $-3: 09: 57$ & $11: 55: 06$ & $-22: 20$ & $8: 23$ \\
\hline Trenggalek & $-3: 05: 04$ & $11: 55: 06$ & $-26: 48$ & $8: 23$ \\
\hline Lemong & $-3: 27: 02$ & $11: 55: 06$ & $0: 05: 24$ & $8: 34$ \\
\hline Anyer & $-3: 17: 10$ & $11: 55: 06$ & $-0: 03: 52$ & $8: 34$ \\
\hline Serang & $-3: 16: 43$ & $11: 55: 06$ & $-0: 04: 36$ & $8: 34$ \\
\hline Gombong & $-3: 04: 42$ & $11: 55: 06$ & $-0: 18: 04$ & $8: 32$ \\
\hline Kebumen & $-3: 04: 07$ & $11: 55: 06$ & $-0: 19: 08$ & $8: 32$ \\
\hline Kulon Progo & $-3: 02: 11$ & $11: 55: 06$ & $-0: 20: 28$ & $8: 32$ \\
\hline Sebalknya tan & 16 cengan & posi & \\
\hline
\end{tabular}

Sebaliknya tabel 16 dengan posisi matahari jauh di Selatan kakbah dan posisi letak geografis daerah yang beragam dari kakbah mempengaruhi saat terjadinya rasyd al-qiblah di berbagai daerah di Indonesia, yakni pagi hari dengan waktu yang bervariasi tergantung letak geografis dari kakbah. Hal ini berarti selain dipengaruhi oleh posisi matahari dari kakbah juga dipengaruhi oleh letak geografis dari kakbah di Mekah, Pengaruh posisi matahari jelas karena semakin jauh posisi matahari dari kakbah nilai sudut (c-p) semakin kecil, jika sudut (c-p) kecil maka peristiwa rasyd al-qiblah akan terjadi pagi hari.

Sementara pengaruh letak geograis daerah dari kakbah juga ikut mempengaruhi saat peristwa rasyd al-qiblah. Hal ini dapat dipahami bahwa Limapuluh Koto, Tanjung Pandan, Belitung letaknya lebih dekat dengan kakbah baik lintang maupun bujurnya, rasyd al-qiblah terjadi di Limapuluh Koto pukul (07:23), Tanjung Pandan pukul (07:12), daerah Belitung pukul 
(07:10) lebih pagi di banding degan daerah lain termasuk Kota Metro (Lampung) pukul (08:23), Trenggalek pukul (08:23), Gombong pukul (8:32) dan Kulonprogo pukul (08:32).

\section{Penutup}

1. Simpulan

Berdasarkan temuan dan pembahasan mengenai pengaruh posisi matahari dan letak geografis terhadap rasyd al-qiblah harian di Indonesai dengan mengambil sampel 34 daerah secara porposip area sampling, sampel bulan diambil secara porposif sebanyak 6 bulan dan sampel tanggal diambil secara porposional yaitu tanggal 1, 15 dan 30 dari masing-masing bulan kecauli Februari tanggal 1, 14 dan 28.

Setelah data diolah dan dianalisa sesuai dengan kategori data dan pertanyaan penelitian dapat peneliti simpulkan bahwa

a. pengaruh posisi matahari dan letak geografis dari kakbah terhadap rasyd al-qiblah harian di Indonesai sangat besar (sangat signifikan), karena: (1). semakin dekat matahari dari kakbah rasyd al-qiblah terjadi pada sore hari (lebih kurang antara pukul 14:00-17:00) dan waktunya hampir sama bagi seluruh wilayah Indonesia yang terletak di belahan selatan, (2). Semakin jauh posisi matahri dari kakbah rasyd al-qiblah terjadi pagi hari antara pukul (07:00-11:00) dan anara satu daerah dengan daerah lain waktunya tidak sama dengan interval waktu yang juga signifikan, (3). Ketika posisi matahari berada di sekitar khatulistiwa yang berarti tengah-tengah antara garis balik Selatan (Desemebr) dengan kakbah di Mekah, (Juni) rasyd a-lqiblah terjadi antara pukul (11:00-14:00). (4). Wilayah Indonesia yang mengalami rasyd al-qiblah harian hanya wilayah yang letak geografisnya di Selatan khatulistiwa, sedangkan wilayah yang letak geografisnya di Utara khatulistiwa tidak mengalami peristiwa rasyd al-qiblah

b. Posisi matahari dari kakbah lebih dominan mempengaruhi saat peristiwa rasyd al-qiblah dibanding letak geografis karena letak geografis bersifat tetap sedang peristiwa rasyd al-qiblah di lokasi yang sama waktunya berbeda-beda (adakanya pagi, siang dan adakalanya sore hari), disebabkan posisi matahari yang selalu berubah-ubah sepanjang tahun.

2. Saran

Masalah rasydul qiblah ini cukup urgen dalam pengembangan keilmuan terutama astronomi dalam Islam, selain sangat urgen dalam kaitannya dengan penentuan arah kiblat. Dalam kaitan ini peneliti menyarankan perlu adanya penelitian lanjut yang lebih mendalam dan lebih koperhensif dalam rangka pengembangan keilmuan khususnya di bidang astronomi Islamn dan untuk kepentingan praktis pengukuran arah kiblat yang dapat digunakan oleh masyrakat dengan, murah dan akurat 


\section{Daftar Pustaka}

A Jamil dkk, Posisi Matahari Sebagai Metode Penentuan Arah Kiblat (Rasydhul Qiblah Harian Sebagai Metode Mengukur Arah Kiblat, laporan penelitian P3M STAIN Jurai Siwo Metro tahun 2014.

------, Toleransi Rasydul Qiblah Global Dalam Penentuan Arah Kiblat,Laporan Penelitian P3M STAIN Jurai Siwo Metro.

-------, Arah Kiblat Indonesia, Jakarta: Rajawali Pres dan STAIN Jurai Siwo Metro, 2010

A Jamil dan Sakirman, Rasydul Qiblah Dunia dan Kalender Rasydul Qiblah Indonesia, STAIN Jurai Siwo Metro 2015

Azhari,Susiknan,Ensiklopedi Hisab Rukyat, Yogyakarta: Pustaka Pelajar, 2008

------, Ilmu Falak; Perjumpaan Khazanah Islam dan Sains Modern, Yogyakarta: Suara Muhammadiyah, 2007

Khafidz, Penentuan Arah Kiblat, Materi Pelatihan Penentuan Arah Kiblat Cibinong: 2009

Khazin, Mukhyiddin,Ilmu Falak dalam Teori dan Praktek: Perhitungan Arah Kiblat, Waktu Shalat, Awal Bulan, dan Gerhana, Yogyakarta: Buana Pustaka, t.t

Kepres No 41 Tahun 1987 Tentang Pembagian Wilayah Menjadi Tiga Wilayah Waktu

Moleong, Lexy J, Metodologi Penelitian Kualitatif, Bandung: Remaja Rosdakarya, 2007

Nazir, Moh, Metode Penelitian, Jakarta: Ghalia Indonesia, 1988

Sukmadinata, Metode Penelitian Pendidikan, Bandung: Remaja Rosdakarya, 2006

Tjasyono, B., Ilmu Kebumian dan antariksa, Bandung: Remaja Rosda Karya,2008 